Hanna Kozińska-Witt*

Rostock

\title{
Przedsiębiorczość jako działalność patriotyczna? Zakłady Baruchów i Włodzimirskich w Podgórzu i Łagiewnikach w drugiej połowie XIX w.*
}

\begin{abstract}
Absctact
The article examines the growth and decline of the one most important industrial enterprise in Podgórze, in the direct vicinity of Kraków, where during the second half of $19^{\text {th }}$ century Maurycy Baruch founded a flourmill, automatic bakery, as well as briquette and tile factories. Baruch managed his business complex until his death, when it was taken over by his offspring. The history of the Baruch enterprises, in particular their modernization and marketing/promoting strategy, is presented in the context of contemporary Galician and Habsburg business competition. The main sources include is the local press, mostly from Kraków.
\end{abstract}

Keywords: Industralization, Galicia, $19^{\text {th }}$ century, Podgórze, millery, bakery, ceramic industry, local exhibitions

Słowa kluczowe: Uprzemysłowienie, Galicja, XIX wiek, Podgórze, młynarstwo, piekarstwo, przemysł ceramiczny, wystawy krajowe

Pod koniec XIX w. anonimowy autor charakteryzował Podgórze w następujący sposób:

Piece fabryczne, ku mnie wznoszące się kominy, jak i unoszące się z nich chmury dymu, robią wielkie wrażenia na podróżnych jadących pociągami kolei Karola-Ludwika, czy linii transwersalnej oraz wskazują na to, że w tej miejscowości

\footnotetext{
*Badaczka niezależna, Rostock; e-mail: kozinska@web.de; ORCID iD: 0000-0003-18068305

** Tekst powstał w ramach projektu Opus 2018/31/B/HS3/03657 „Rola Żydów w życiu gospodarczym Krakowa i okolic w okresie autonomicznym”, finansowanego przez Narodowe Centrum Nauki. Dziękuję kierownikowi projektu, dr. Przemysławowi Zarubinowi i współpracowniczce - dr Alicji Maślak-Maciejewskiej za krytyczną lekturę tekstu i dostarczanie materiałów źródłowych. P. dr Kamili Follprecht dziękuję za bardzo pomocne uwagi i udostępnienie nieopublikowanych tekstów.
} 
[Podgórze] nie można skarżyć się na bezrobocie, niedostatek czy biedę i wielu pasażerów błogosławi tych, którzy urządzili i stale utrzymują fabryki dla korzyści i błogostanu [miejscowej] ludności ${ }^{1}$.

Do produkcji tych - optymizmem napawających - chmur dymu walnie przyczyniały się kominy przedsiębiorstw baruchowskich.

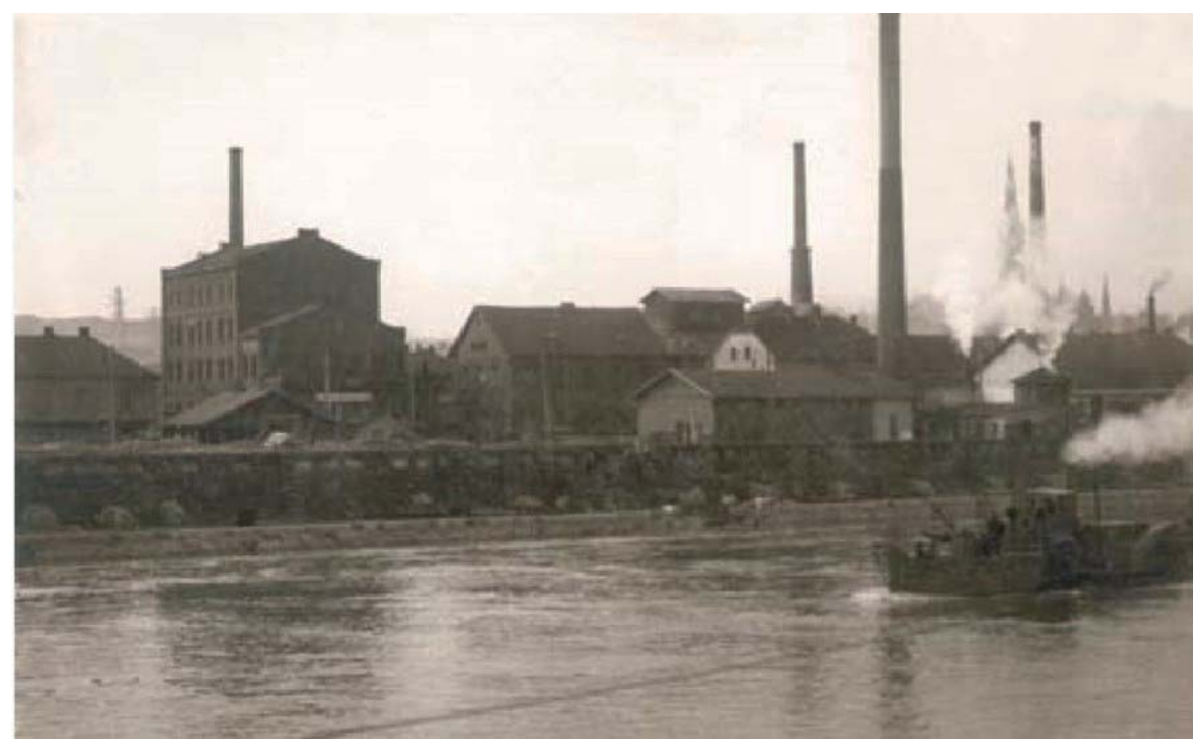

Fot. 1. Przedsiębiorstwo Barucha w Podgórzu, koniec XIX w. ANK A-IV-672.

Oprócz fabryki Zieleniewskiego były to w drugiej połowie lat sześćdziesiątych XIX wieku najważniejsze zakłady przemysłowe w okolicach Krakowa $^{2}$. Założycielem przedsiębiorstwa był Maurycy Baruch, którego Karolina Grodziska nazywa „(...) pionierem nowoczesnego przemysłu spożywczego”3. Natomiast Juliusz Demel pisał o nim, że „(...) nie będąc ani młynarzem, ani piekarzem, ani chemikiem, jest w zakresie produkcji swoich własnych zakładów przemysłowych właściwie dyletantem"4. Mimo to Baruch opanował, według Demla, podstawowe zasady prowadzenia przedsiębiorstwa dochodowego i właśnie to przyczyniło się do jego sukcesu.

${ }^{1}$ Die jüdische Industrie im krakauer [!] Rayone, „Sprawiedliwość Die Gerechtigkeit” 7, 1.04.1898, s. 1. Wszystkie tłumaczenia są moje.

2 J. Demel, 1967, s. 16 i n.

${ }^{3}$ K. Grodziska, 2003, s. 88.

${ }^{4}$ J. Demel, 1958, s. 93. Natomiast świadek epoki, Kazimierz Gitler, wspominał, że „spekulant" Baruch terminował u Kirchmayera w Pleszowie, a pochodził z Krzeszowa, K. Girtler, 1971, s. 51. 
Pisząc tę charakterystykę Demel miał prawdopodobnie przed oczami innego krakowskiego przedsiębiorcę, Ludwika Zieleniewskiego, który był mistrzem kowalskim czyli fachowcem. Demel wspomniał również, że Maurycy doszedł do wielkiego majątku i stał się posiadaczem zakładów przemysłowych w Podgórzu i Łagiewnikach. Ponieważ potomkowie Maurycego na początku wieku XX sprzedali wszystkie zakłady, więc zasadne wydaje się postawienie pytania, co było przyczyną zaniechania działalności. Czyżby historia firmy ilustrowała starą maksymę: dziad założył, syn utrzymał, a wnuk przeputał? Jak odnosiła się do przedsiębiorców gmina żydowska? Aby odpowiedzieć na te pytania, postaram się przedstawić rozwój przedsiębiorstw w kontekście regionu i Monarchii. Ponieważ nie zachowały się archiwalia firmy, więc źródeł do tego artykułu dostarczyła mi przede wszystkim krakowska prasa: anonsy reklamujące produkty firmy, sprawozdania $z$ wystaw oraz informacje o pracownikach i stosunkach między przedsiębiorcami, a zatrudnionymi ${ }^{5}$. Koligacje rodzinne Baruchów przedstawiam w osobnym artykule ${ }^{6}$. Na potrzeby tego tekstu wystarczy informacja, że założycielem przedsiębiorstwa był Maurycy Baruch (1800-1874), kontynuatorami - jego synowie Emil (1832-1886) i Gustaw (1838-1907), a ostatnim przedsiębiorcą w rodzinie wnuk Maurycego i syn Emila, Karol Włodzimirski (1865-1932).

\section{Młyn parowy}

Maurycy Baruch zajmował się początkowo spławem soli do Królestwa Polskiego ${ }^{7}$. W 1848 razem z [Władysławem Maurycym] Koliszerem i nieznanym z imienia Stohnem założył parowy młyn mączny w Podgórzu ${ }^{8}$. Powstanie tego przedsiębiorstwa wiązało się ściśle z rozwojem połączeń kolejowych umożliwiającym na większą skalę przywóz zboża i wywóz mąki ${ }^{9}$. Jak wskazywał Adolf Lipp, zaangażowanie w młynarstwo łączyło się z pewnym ryzykiem finansowym, albowiem za zboże płacono z góry, chociaż dostawę realizowano dopiero po kilku miesiącach ${ }^{10}$. Ponieważ mąkę sprzedawano na kredyt, więc właściciel młyna musiał posiadać duży kapitał. Lipp pisał, że sprzedaż wyrobów była organizowana przez samego właściciela młynów, który musiał być zarazem obrotnym kupcem ${ }^{11}$.

${ }^{5}$ Przejrzałam „Czas” (1850-1900), „Nową Reformę” (1882-1914) [dalej NR], „Głos Narodu” (1883-1914) [dalej GN], „Naprzód” (1892-1914), „Sprawiedliwość Die Gerechtigkeit” (1893-1903) [dalej SG], „Przemysłowca” (1903-1911), „Podgórzanina” (1900), „Gazetę Młynarską” (1886-1889) i fragmentarycznie „Przemysł ceramiczny” (1901-1903).

${ }^{6}$ Wzloty i upadki przemysłowców okolic Krakowa: Maurycy Baruch i jego potomkowie, [w:] Wydawnictwo Ośrodka Studiów nad Historią i Kulturą Żydów Krakowskich, Instytut Judaistyki UJ (w przygotowaniu).

J. Demel, 1958, s. 49-51.

${ }^{8}$ M. Baruch, Nadesłane, „Czas”, 179, 7.08.1860, s. 4.

9 T. Rutkowski, 1886, s. 27.

10 A. Lipp, 1870, s. 21.

11 A. Lipp, 1970, s. 29. 


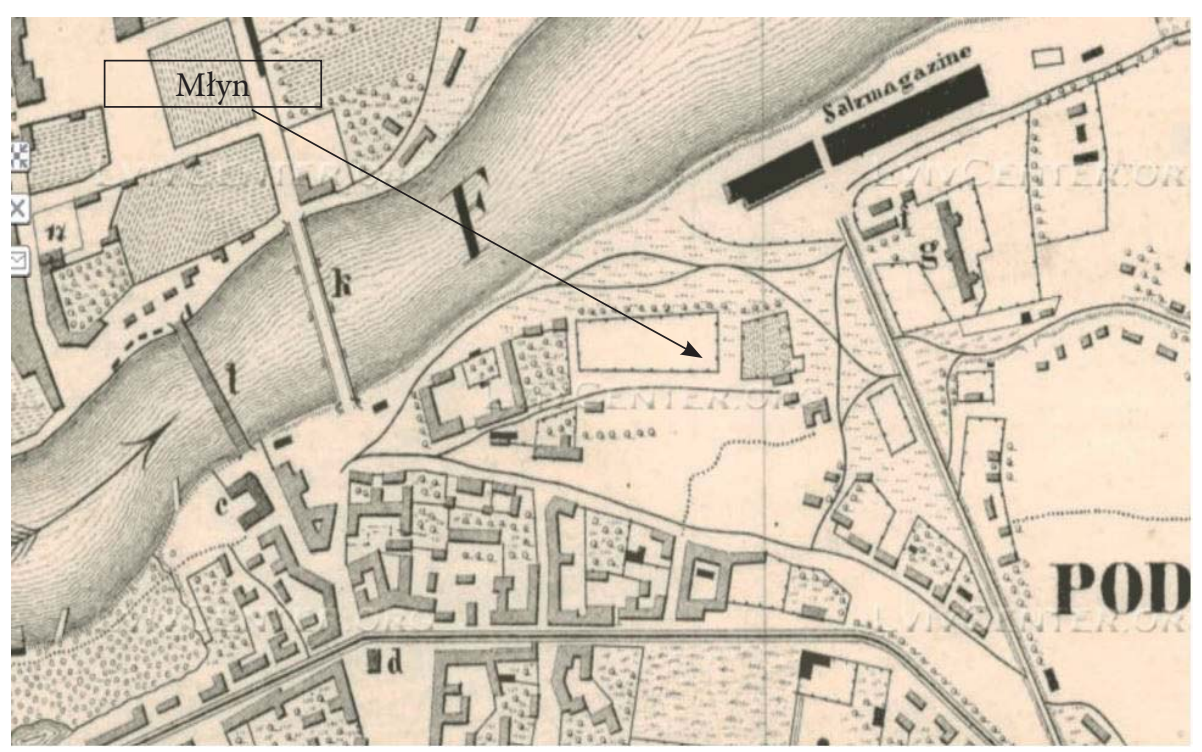

Fot. 2. Plan Podgórza 1848 , fragment ${ }^{12}$

W latach pięćdziesiątych Maurycy przejął zbankrutowane fabryki Steinkellerowskie w Podgórzu: kościarnię do wyrobu spodium (tzw. węgla kostnego) dla cukrowni, mączki nawozowej, młyn do mielenia gipsu oraz fabrykę wyrobów glinianych, cegieł, dachówek, drenów, pieców i ornamentów ${ }^{13}$. W ten sposób w roku 1854 stał się właścicielem młyna parowego do mielenia gipsu (nawozy sztuczne), który reklamowano w „Czasie” ${ }^{14}$. Później ten młyn przerobiono na mączny.

Młyn obsługiwała początkowo jedna maszyna parowa o sile 35 koni mechanicznych (1851), a od 1859 już dwie, o sile 55 koni, które wprawiały w ruch 11 kamieni. Firma posiadała dopływ gazu z gazowni krakowskiej. Przedsiębiorstwo dysponowało kapitałem obrotowym 100.000 złr. (1860), zatrudniało 30 do 35 ludzi i sprzedawało wyroby do Krakowa i Galicji1 ${ }^{15}$. Młyny Barucha, jak i inne młyny galicyjskie, były obliczone mniej więcej na roczny przerób 60000 korcy pszenicy, a uzyskane w ten sposób mąki handlowe były przeznaczone na eksport ${ }^{16}$. I tak młyn Barucha dostarczał dużej ilości mąki do Królestwa

${ }_{12}$ Plan von Krakau mit Podgorze und der nächsten Umgebung. Herausgegeben und litographirt von Alexander Kocziczka k.k. Unterlieutenant im 39ten L.I.R. Dom Miguel. Olmütz. 1847, Österreichiches Kriegsarchiv, Wien AT-OeStA/KA KPS KS G I h, 338, [w:] https://www. lvivcenter.org/pl/umd/map/?ci_mapid=120 [dostęp: 20.07.2020].

13 T. Rutkowski, 1886, s. 19; O Steinkellerze obszernie B. Kostuch, 2011, s. 231, przypis 26.

14 Ogłoszenie, „Czas” 18, 23.01.1857, s. 4.

15 Przegląd usiłowań rolniczo-przemysłowych, „Czas” 123, 2.06.1855, s. 2.

16 T. Rutkowski, 1886, s. 20. 
i Warszawy, ale też do Prus ${ }^{17}$. Maurycy zatrudniał najpierw „cudzoziemców”, którzy następnie szkolili swoich - już polskich - następców ${ }^{18}$.

Tadeusz Rutkowski opracowujący statystykę młynów w Galicji oceniał, że Baruch położył ogromne zasługi dla rozwoju młynarstwa krajowego i wiązał ten rozwój z historią kolei żelaznych i wydobyciem węgla kamiennego. Sam Maurycy chełpliwie podkreślał znaczenie firmy na rynku ogólnoeuropejskim, co umożliwiła mechanizacja produkcji:

W ten sposób otworzyłem wyrobom moim drogę na wszystkie targi krajowe i zagraniczne, a nawet na targ londyński, gdzie też wyroby te nie bez korzyści $\mathrm{z}$ wyrobami francuskiemi, hiszpańskiemi i niemieckiemi współzawodnictwo wytrzymują ${ }^{19}$.

Znaczenie firmy polegało nie tylko na ożywieniu miejscowego przemysłu i zapewnieniu zatrudnienia miejscowej ludności, ale miało także wymiar finansowy. W latach osiemdziesiątych młyny baruchowskie znajdowały się w pierwszej dziesiątce najwyżej opodatkowanych przedsiębiorstw w Galicji na ogólnie 35 ( $210 \mathrm{złr})^{20}$.

Z ogłoszeń prasowych wynika, że zakład bez przerwy modernizowano i powiększano, w związku z czym czasowo zamykano (np. w 1864) ${ }^{21}$. Opublikowany w „Czasie” w 1864 roku „anons dziękczynny” adresowany do firmy Józefa Osera w Krems informował, skąd Maurycy sprowadzał kamienie młyńskie do swojej fabryki: po wypróbowaniu fabrykatów wrocławskich, berlińskich i francuskich przeważyły zalety kamieni z Dolnej Austrii22 ${ }^{2}$. Ogłoszenie świadczyło o tym, że przedsiębiorca drogą prób i błędów ciągle poszukiwał optymalnych rozwiązań i urządzeń. Idąc z duchem czasu zaprowadzono w młynach system mielenia dający „piękniejsze mąki” i lepiej wyzyskujący ziarno ${ }^{23}$. Modernizacja młynów powodowała wysprzedaż przestarzałych narzędzi, np. francuskich starych kamieni młyńskich, „(...) dających się korzystnie użyć do mniejszych młynów”"24.

${ }^{17}$ Kronika, „Czas”, 232, 9.10.1867, s. 2; A. Lipp, 1870, s. 27.

18 O konieczności sprowadzania fachowego personelu z krajów sąsiednich, patrz A. Lipp, 1870, s. 21.

${ }_{19}$ M. Baruch, Nadesłane, „Czas” 179, 7.08.1860, s. 4. Baruch nie brał udziału w międzynarodowej wystawie w Paryżu w r. 1867, w każdym razie w katalogu oddziału austriackiego jego nazwisko nie figurowało. Internationale Ausstellung zu Paris 1867. Katalog der österreichischen Abtheilung, Wien [b. d.].

20 T. Rutkowski, 1886, s. 32. Wyprzedzały je młyny Deymonda w Szczepanowicach, Raucha w Sokalu, Pnińskiego w Grzymałowie, Weishausa w Stanisławowie, Bluechera w Ujściu Biskupim, Freunda, Szancera i Lorda w Tarnowie, Wodzickiego w Tenczynie oraz Thoma w Lwowie. Ceny różnych gatunków mąki baruchowskiej, patrz A. Lipp, 1870, s. 29.

${ }^{21}$ Gospodarstwo, przemyst $i$ handel, „Czas” 200, 2.09.1865, s. 3.

${ }^{22}$ Ważne doniesienie dla Właścicieli młynów parowych i wodnych względem kamieni młyńskich, „Czas” 20, 24.04.1864, s. 4. Fabryka maszyn i odlewnia żelaza mistrza młynarskiego Józefa Osera produkowała turbiny i kamienie młyńskie, które rozprowadzała w całej Monarchii, patrz H. Frühwirth, 2000, s. 255.

${ }^{23}$ T. Rutkowski, 1886 , s. 20.

${ }^{24}$ W młynach parowych Maurycego Barucha w Podgórzu..., „Czas”260, 13.11.1874, s. 4. 
W roku 1885 młyny powiększono, o czym świadczy zamieszczone w prasie ogłoszenie:

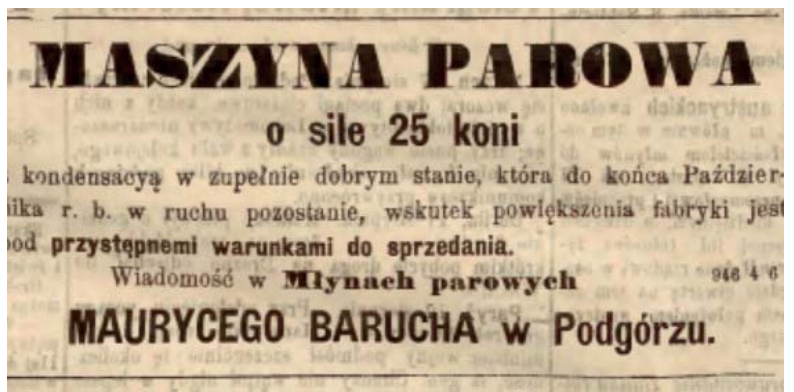

Fot. 3. NR 186, 18.08.1885; s. 4; ', Czas" 185, 15.08.1885, s. 6.

W tym samym czasie w młynie zamontowano dwa walce obrączkowe (Ringwalzenstuhlgang) firmy Ganz i S-ka z Budapesztu ${ }^{25}$. Powiększała się tė̇ liczba zatrudnionych: według „Naprzód” w r. 1895 w samych młynach pracowało już 65 osób $^{26}$. Wydaje się, że z czasem zmniejszyło się znaczenie eksportów mąki za granicę, natomiast wzrosła rola dostaw dla wojska (mlewo wojskowe) ${ }^{27}$. Ponieważ młyny Barucha leżały w Podgórzu, więc właściciel nie musiał płacić ani akcyzy, ani myta, a dowóz kosztował go mniej niż krakowskich konkurentów (chodzi o młyny królewskie hr. Konstantego Reya), a więc mógł produkować z zyskiem.

Przedsiębiorstwo było miejscowym wzorem nowoczesności: w roku 1883 zakłady fabryczne Barucha oświetlano elektrycznie „sześcio-arkadowymi lampami” systemu Zypernowskiego ${ }^{28}$ (wykonanymi przez wymienioną już firmę Ganz i Spółka z Budapesztu), które krakowska rada miejska, po najwyraźniej udanym eksperymencie baruchowskim, chciała zastosować do oświetlenia Rynku Głównego ${ }^{29}$. Oświetlenie elektryczne miał wprowadzić w zakładach Emil Baruch, który „(...) [z]aprowadzał w swoich młynach jakoteż [!] fabrykach wszelkie najnowsze zmiany i ulepszenia na korzyść przemysłu krajowego, nie szczędząc kosztów ani trudów (...)"30.

${ }^{25}$ Nadestane, „Gazeta Młynarska” 3, 10.07.1886, s. 5. Ganz i S-ka, Odlewarnia żelaza i akcyjne Towarzystwo fabryczne dla budowy machin w Budapeszcie i Raciborzu (1887), później Ganz i S-ka w Budapeszcie, Towarzystwo akcyjne fabryki odlewów, budowy machin i wozów (Ganz es tarsa vasontode es gepgyar reszvenytarsulat waggongyara, 1901). Przedsiębiorstwo Ganza reklamowano w każdym numerze „Gazety Młynarskiej”.

${ }^{26}$ Kronika, „Naprzód” 21, 24.05.1895, s. 3.

27 Zbrodnia oszczerstwa, „Gazeta Młynarska” 1, 10.02.1888, s. 4.

${ }^{28}$ Wynalazcą tego rodzaju oświetlenia elektrycznego był Karol Zipernowsky, patrz: Zipernowsky Karol, [w:] https://de.wikipedia.org/wiki/K\%C3\%A1roly_Zipernowsky (21.07.2020).

${ }^{29}$ Kronika, „Czas” 187, 19.08.1883, s. 2; Sprawy miejskie, NR 151, 7.07. 1883, s. 2; Kronika, NR 165-166, 25.07.1883, s. 4; Kronika, NR 168, 27.07.1883, s. 3; Kronika, NR 169, 28.07.1883, s. 3. Według Rutkowskiego tylko młyny baruchowskie były oświetlane elektrycznie, T. Rutkowski, 1886, s. 33.

${ }^{30}$ Emil Baruch, „Gazeta Młynarska” 8, 21.12.1886, s. 1. 
„Młyn amerykański” służył nie tylko szkoleniu młodzieży z krakowskiego Instytutu Technicznego ${ }^{31}$. Młyny stały się także przedsiębiorstwem pokazowym, które znajdowało się na trasie odwiedzających Kraków wycieczek, np. słuchaczy piątego roku politechniki wiedeńskiej, czy chemików lwowskich ${ }^{32}$. W Krakowie Maurycy sprzedawał cały asortyment produktów przedsiębiorstwa (tzn. też cegłę i kafle) początkowo w sklepie własnym na Floriańskiej (1860), potem w Rynku Głównym u Milieskiego ${ }^{33}$, a wreszcie w składzie Hochstima przy ul. św. Jana. Wyroby baruchowskie były tak popularne, że sprzedawano je bez koncesji także w innych sklepach ${ }^{34}$.

\section{Piekarnia}

Z wiosną 1865 Maurycy rozpoczął budowę wielkiej piekarni mechanicznej przy młynie. W czerwcu 1865 gazeta „Krakauer Zeitung” donosiła, że „Pan Baruch ma zamiar otworzyć dużą piekarnię w Podgórzu, która będzie dostarczać bezkonkurencyjnie taniego chleba" ${ }^{35}$. Zbudowano ją przy ul. Nadwiślańskiej $194^{36}$. Zarząd objął syn Gustaw. Piekarnię obsługiwała maszyna o mocy 10 koni, sprowadzona - podobnie jak i piece - $\mathrm{z}$ fabryki J. Hofmanna we Wrocławiu ${ }^{37}$.

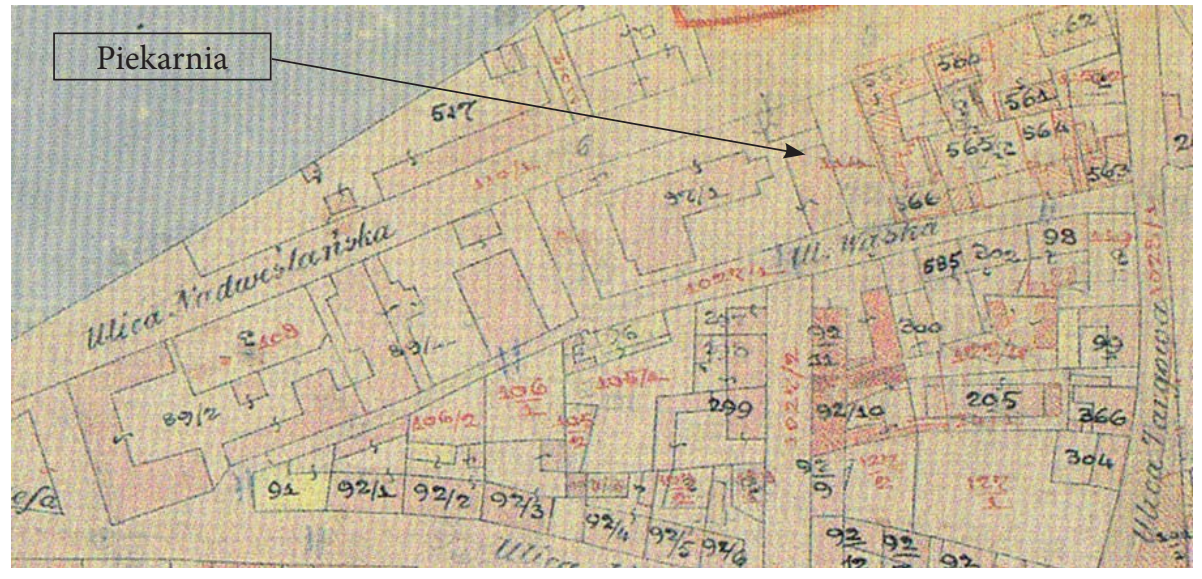

Fot. 4. Podgórze 1904, ANK KPK 95, fragment

${ }^{31}$ B. Kostuch, 2011, s. 233, p. 41. Tzw. amerykański system mielenia zboża był całkowicie zmechanizowany i polegał na używaniu do mielenia kwarcowych kamieni przy zastosowaniu żelaznych konstrukcji, centralnego napędu oraz lepszego procesu segregowania i oczyszczania zboża.

${ }^{32}$ Kronika, „Czas” 118, 25.05.1887, s. 2; Kronika, „Czas”178, 6.08.1889, s. 2.

${ }^{33}$ Reklama, „Czas” 66, 21.03.1871, s. 5. „Czas” wspominał o wystawie Barucha w sklepie obok pałacu pod Baranami, Kronika, „Czas”146, 28.06.1867, s. 2.

${ }^{34}$ Ogłoszenia, NR 16, 19.01.1884, s. 4.

35 „Krakauer Zeitung” 3.06.1865, s. 3.

36 A. Nowolecki, 1878, s. 235 i 255.

${ }^{37}$ Nie udało mi się wyjaśnić, czy chodziło o Waggonfabrik Gebr. Hofmann \& Co. Aktiengesellschaft. 


\section{NOWA PIEKARNIA PAROWA.}

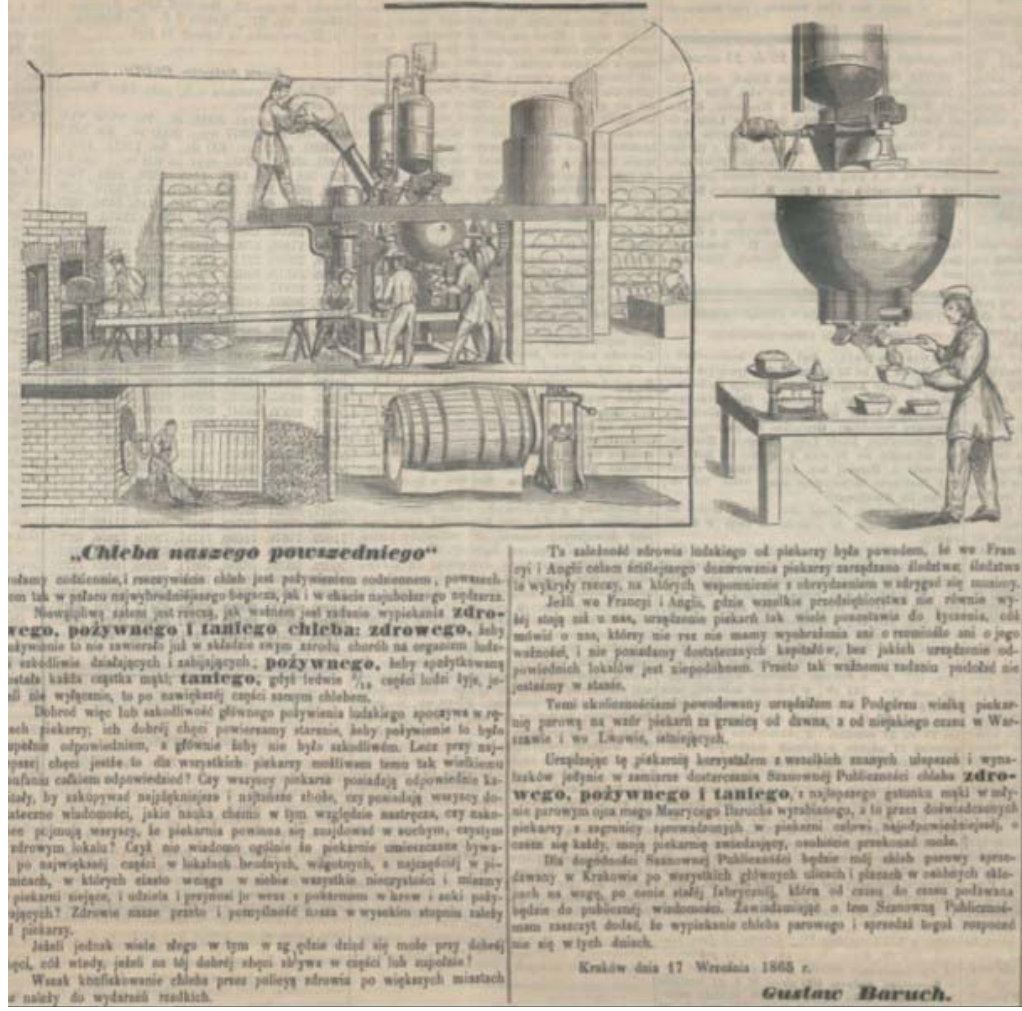

Fot. 5. „Czas" 216, 22.09.1865, s. 4.

Ogłoszenie anonsujące otwarcie piekarni zapowiadało, że chleb w niej wyrabiany będzie nie tylko tani, ale przede wszystkim pożywny i zdrowy, a to dlatego, że założycieli stać [wytłuszczenie HKW] na zbudowanie odpowiedniej fabryki oraz zapewnienie kompetentnej i higienicznej fabrykacji ${ }^{38}$. Wzmiankowana była też współpraca między przedsiębiorstwami baruchowskimi: młyn ojca Maurycego dostarczał wyśmienitej mąki, którą w najwydajniejszy z możliwych sposobów użytkowała piekarnia syna. Wraz z objęciem zarządu piekarni Gustaw Baruch wniósł popartą przez krakowską IPH prośbę do Namiestnictwa, aby założona przez niego [!] piekarnia parowa mogła używać godła „uprzywilejowana piekarnia chleba parowego” ${ }^{39}$. W r. 1866 prośbę rozpatrzono pozytywnie. Zakład używał nazwy „Uprzywilejowana c.k. piekarnia chleba parowego" oraz zamieszczał orła cesarskiego na znaku pieczęci ${ }^{40}$. Prawdopodobnie założenie piekarni pozostawało w związku z wewnętrznym

${ }^{38}$ Nowa piekarnia parowa, „Czas” 216, 22.09.1865, s. 4.

39 „Krakauer Zeitung” 15.01.1865, s. 2.

40 Gospodarstwo przemyst $i$ handel, "Czas” 8, 12.01.1866, s. 3; „Krakauer Zeitung” 31.03.1866, s. 3 . 
podziałem przedsiębiorstwa: w r. 1866 wpisano do rejestru handlowego młyn Gustawa Barucha ${ }^{41}$. Tak więc wprawdzie przedsiębiorstwo było własnością obu braci, Emila i Gustawa, ale piekarnia parowa znajdująca się na obszarze zakładu była już własnością Gustawa.

O asortymencie piekarni i miejscach sprzedaży informowało ogłoszenie z 1891 r.:

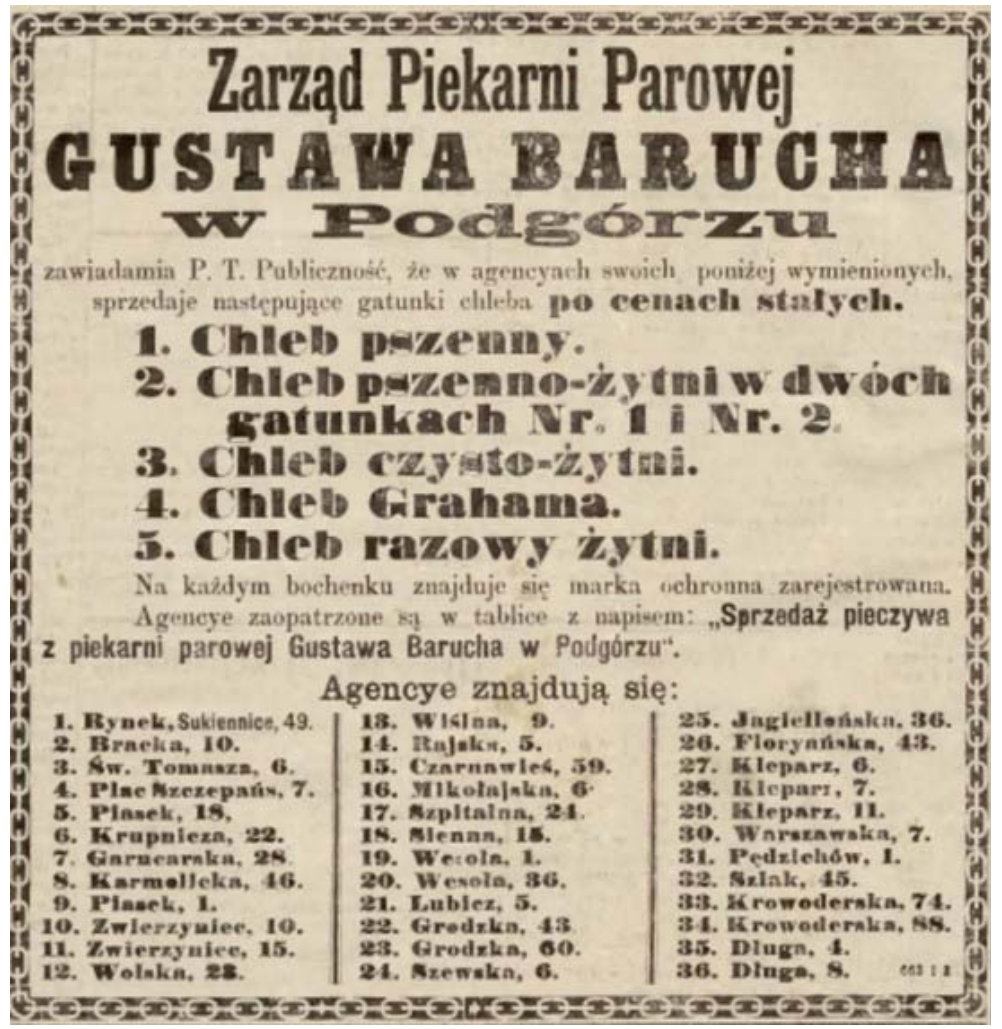

Fot. 6. NR 60, 14.03.1891, s. 4.

Specjalnością piekarni były m.in. suchary, tj. produkt o długotrwałej przydatności, które produkowano dla wojska. W r. 1878 „Przegląd Lekarski” bardzo wysoko je ocenił, bowiem wyróżniały się dobrą mąką i przyjemnym smakiem $^{42}$. Na początku lat 90. Gustaw poszerzył swój asortyment o chleb żytni, dotąd importowany z Moraw.

${ }^{41}$ Aleksander Nowolecki podawał w r. 1878, że właścicielem piekarni parowej był Emil Baruch, patrz A. Nowolecki, 1878, s. 13. W r. 1890 prokurystą przedsiębiorstw Gustawa został jego najstarszy syn, Juliusz Baruch, zm. 1906.

${ }^{42}$ Kronika, „Czas” 224, 29.09.1878, s. 3. 


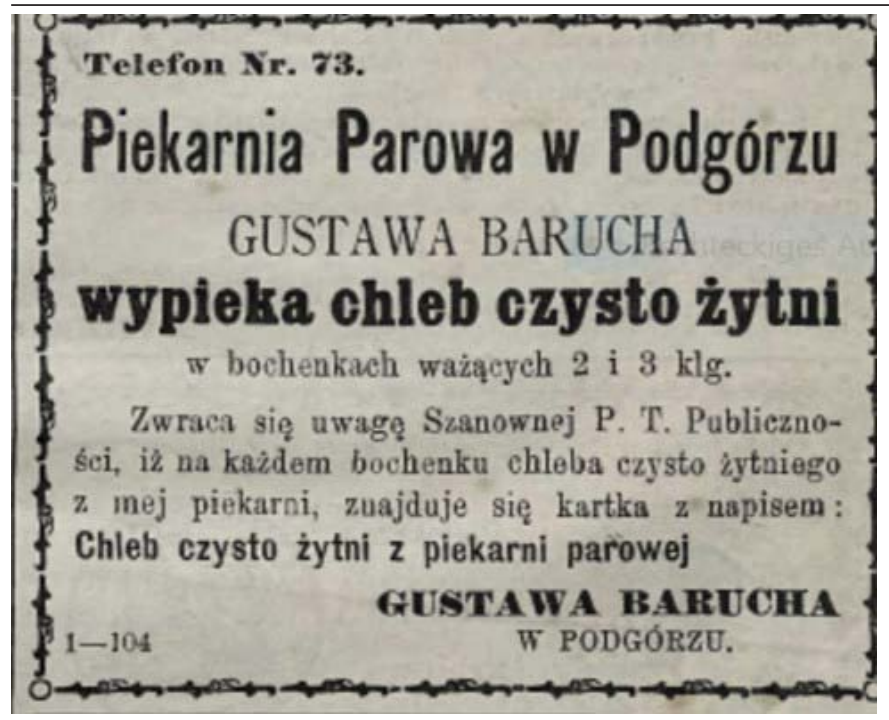

Fot. 7. „Głos Narodu”1, 28.11.1893, s. 15.

Na popularność tego produktu wpłynęły zalecenia higienistów i lekarzy, którzy - zgodnie z aktualnymi trendami - oraz częściej zalecali „odwrót od białego pieczywa”" ${ }^{43}$. Wobec braku odpowiedniego produktu krajowego zaczęto masowo sprowadzać chleb żytni z Moraw, „(...) i w ten sposób dotkliwa klęska spadła na przemysł miejscowy. Zalewani mąką węgierską, zaczęliśmy czuć napływ chleba morawskiego w kraju nawskróś [!] rolniczem" ${ }^{44}$. Gustawa przedstawiano (czy raczej sam się przedstawiał), jako patriotę ratującego przemysł lokalny:

Wobec takiego stanu rzeczy p. Gustaw Baruch, znany przemysłowiec, chcąc zapobiedz [!] sprowadzaniu obcego chleba, założył oddział osobny w swej parowej piekarni, celem wypiekania żytniego chleba”.

Aby umożliwić wypiek, do Krakowa sprowadzono doświadczonych fachowców piekarskich z Moraw, którzy mieli przyuczyć miejscowych pracowników. W ten sposób Gustaw rozpoczął walkę konkurencyjną z chlebem morawskim, którą niebawem wygrał:

(...) chleb żytni p. Barucha znajduje coraz szerszy odbyt dzięki zaletom swym, mianowicie doborowemu celnemu ziarnu żytniemu bez przymieszek i należytemu wypieczeniu, o co tak trudno przy chlebie czysto żytniem. Chleb ten ma ciemną naturalną barwę z powodu tego, że zachowano w nim pożywne wszystkie pierwiastki i dlatego właśnie jest cenionym przez publiczność. Znawcy uznali, że chleb żytni p. Barucha ma wszystkie warunki, wymagane do tego rodzaju pieczywa. Tak

${ }^{43}$ Dział ekonomiczny, „Czas” 20, 25.01.1893, s. 3.

44 Ibidem. 
więc działalność zakładów p. Barucha i w tej sprawie okazała się pożyteczna dla krajowego rolnictwa i przemysłu ${ }^{45}$.

„Nowa Reforma” komentowała: „Jak wszelkie usiłowania wypierania z kraju i miasta obcych produktów przemysłu, tak i to przedsięwzięcie pp. Baruchów polecamy poparciu publiczności" ${ }^{46}$. Chleb rozprowadzano w całej Galicji: można go było kupić w ajencjach piekarni w Wieliczce, Tarnowie, Bochni, ale też w Chrzanowie, Rzeszowie, Przemyślu, Lwowie i Suchej.

Hossa Gustawa skończyła się w drugiej połowie lat dziewięćdziesiątych. W roku 1897, prawdopodobnie w związku z oskarżeniem o działanie na szkodę gminy Podgórze w ramach kartelu wapienniczego, ukazała się wzmianka, że zakłady fabryczne Gustawa Barucha (wielki młyn na żyto i olbrzymia piekarnia wraz z budynkami mieszkalnymi i administracyjnymi) mają przejść na własność Towarzystwa akcyjnego pod protektoratem galicyjskiego Banku dla Handlu i Przemysłu ${ }^{47}$. Antysemicki „Głos Narodu” sprostował tę wiadomość: „Młyny nabyli niestety [kursywa HKW] Żydzi Rabinowicz i Aratin [!]”48. Piekarnia Gustawa została w roku 1898 sprzedana, a o Gustawie wspominano już jedynie jako o właścicielu realności w Podgórzu ${ }^{49}$. Nowi właściciele korzystali jednak chętnie z dobrego imienia poprzednika. W „Czasie” zawiadamiano, że piekarnia higieniczna-parowa, dawniej uprzywilejowana piekarnia Gustawa Barucha, będzie dalej, jak od 50 lat, wypiekać chleb czysto żytni, „znany ze swej dobroci, a przewyższający tak pod względem spożywczym, jak i higienicznym wyrobem morawski i inny" 50 .

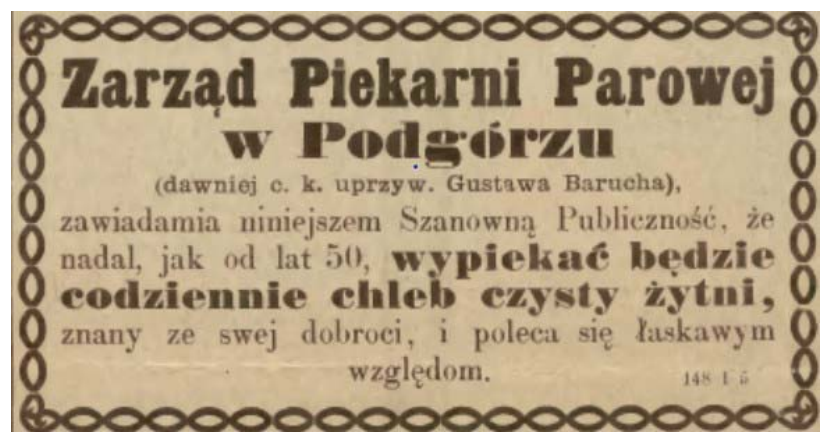

Fot. 8. NR 6, 9.01.1898, s. 6.

45 Ibidem.

${ }^{46}$ Kronika, NR 4, 5.01. 1892, s. 2.

${ }^{47}$ Kronika, GN 199, 2.09.1897, s. 4.

${ }^{48}$ Był to ojciec Michaliny Araten, która uciekła z chasydzkiego domu, aby przejść na katolicyzm i wyjść za chrześcijanina. Jej sprawa była jedną z najsłynniejszych afer typu „Mädchenraub”, patrz T. Buchen, 2010, s. 205-208; Kronika, „Czas” 40, 16.02.1900, s. 2. O Arthenie [!] jako współwłaścicielu młynów pobaruchowskich, patrz Kronika, „Podgórzanin” 4, 21.01.1900, s. 5.

${ }^{49}$ Kronika, NR 225, 2.10.1898, s. 2.

50 Zarząd piekarni parowej w Podgórzu, „Czas” 22, 28.01.1898, s. 4. 
Piekarnia dalej używała stempla „Erste galizische Dampfmühle und Dampfbäckerei in Podgórze" ${ }^{11}$. Z niewiadomych względów młyn baruchowski niewiele później zlikwidowano. W r. 1910 wyprzedawano inwentarz:

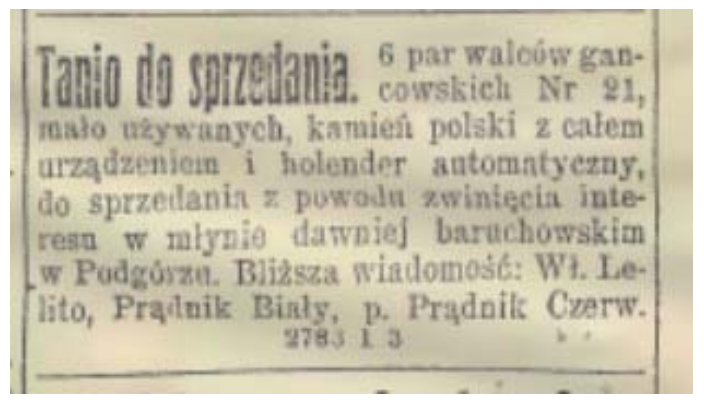

Fot. 9. NR 171, 16.04.1910, s. 8.

\section{Cegielnia i kaflarnia}

Założenie cegielni i kaflarni w Łagiewnikach spowodowane było występowaniem w tej gminie złóż wyborowej gliny ${ }^{52}$. Do sukcesu tutejszej cegielni przejętej przez Maurycego Barucha wydatnie przyczyniło się nasilenie ruchu budowlanego w Krakowie: odbudowa miasta po pożarze 1850 r., rozbudowa fortyfikacji austriackich i budowa mostów przez Wisłę ${ }^{53}$. Ok. 1860 cegielnia produkowała ok. 1,5 mln cegieł rocznie, poza tym dachówki i dreny ${ }^{54}$. Należała do największych zakładów w Galicji. W r. 1903 cegielnia dysponowała jednym piecem kręgowym i jednym czterokomorowym ${ }^{55}$.

Adolf Lipp wskazywał, że - w odróżnieniu od innych produkowanych w Galicji - cegła baruchowska była żaroodporna i że jej głównymi nabywcami były różne instytucje publiczne oraz wojsko, klasztory i zakłady przemysłowe - eksportowano ją aż do Czerniowców ${ }^{56}$. Już po boomie budowlanym, trwającym do końca lat dziewięćdziesiątych XIX w., cegielnia Barucha utrzymała się, mimo małego zbytu na rynku lokalnym i obcej konkurencji ${ }^{57}$. Decydujące znaczenie miała dobra opinia o firmie, która przekładała się na zamówienia samorządowe i rządowe. I tak Magistrat zalecał używać cegłę wyborową od Barucha, wypaloną i z godłem firmy ${ }^{58}$. Dlatego trudno znaleźć w Krakowie projekty budowlane $\mathrm{z}$ drugiej poł. XX w., które nie korzystałyby

${ }^{51}$ Kronika, NR 19, 24.01.1902, s. 2. Karol Włodzimirski prostował, że jego firma „Maurycy Baruch" nie posiada żadnej piekarni Kronika, NR 20, 25.01.1902, s. 2.

${ }^{52}$ Gospodarstwo, przemyst $i$ handel, „Czas” 192, 22.08.1873, s. 3.

53 J. Demel, 1967, s. 5; B. Kostuch, 2011, s. 229 i 233.

${ }^{54}$ J. Demel, 1958, s. 46; A. Partridge, 2017a, s. 186. W r. 1870 już 2 mln cegieł, A. Lipp, 1870 , s. 131.

${ }_{55}$ Cegielnie w Galicyi c.d, „Przewodnik dla ceglarzy”, 17, 10.09.1903, s. 138.

56 A. Lipp, 1870, s. 131 i n.

57 J. Demel, 1958, s. 44 i n.

${ }^{58}$ Kronika, „Czas” 204, 6.09.1889, s. 2. 
z baruchowskej cegły: budowano z niej zarówno wiadukt kolejowy (1864), jak i Collegium Novum (1883-1887) ${ }^{59}$. Firma dostarczyła 700000 tysięcy cegieł dla budownictwa miejskiego, do budowy Szkoły Sztuk Pięknych na Kleparzu i koszar straży pożarnej na Kotłowem ${ }^{60}$. Cegła m.in. od Maurycego Barucha została też zakontraktowana dla budowy teatru ${ }^{61}$. Firma Baruch wykonała również roboty dekarskie w budowanej w r. 1892 szkole przy ul. Dietla ${ }^{62}$, zaś w r. 1896 dostarczała cegły dla kolei państwowej i kościoła św. Krzyża ${ }^{63}$.

Reklama wyrobów kaflarni Barucha zamieszczona w „Czasie” w lipcu 1867 r., w roku założenia kaflarni przy cegielni w Łagiewnikach, przedstawiała wizerunki różnego rodzaju pieców pokojowych i kuchennych oraz kominków produkowanych i ustawianych przez firmę. Według Bożeny Kostuch cieszyły się one w Galicji wielką popularnością ${ }^{64}$. Ogrzewały zarówno budynki prywatne, jak i urzędy ${ }^{65}$.

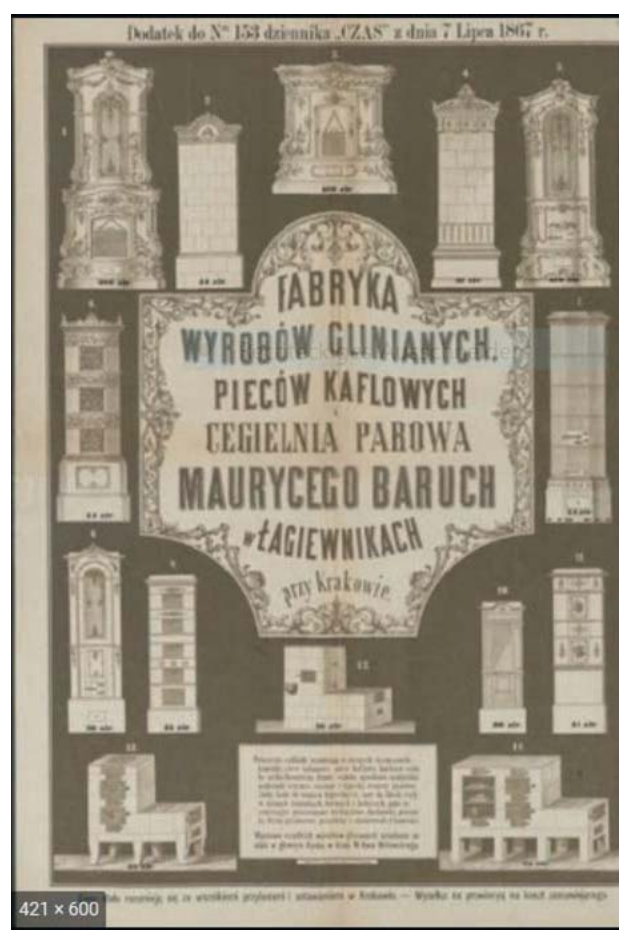

Fot. 10.„CZas" 153, 7.07.1867, s. 4 .

${ }^{59}$ A. Partridge, 2017a, s. 186.

${ }^{60}$ Kraków 17 maja, „Czas” 114, 18.05.1878, s, 2.

${ }^{61}$ Kronika, NR 80, 9.04.1891, s. 3.

${ }^{62}$ Kronika, NR 201, 2.09.1892, s. 2.

${ }^{63}$ Kronika, „Czas” 251, 21.10.1896, s. 3.

${ }^{64}$ B. Kostuch, 2011, s. 234.

${ }^{65} \mathrm{~Np}$. w piece baruchowskie wyposażona była siedziba cesarsko-królewskiego Delegata Namiestnictwa C.K. Starostwa przy ul. Basztowej, A. Partridge, 2017b, s. 407. 
Piece reklamowano jako nieustępujące produktom zagranicznym, oszczędne, łatwe $\mathrm{w}$ obsłudze i bezkonkurencyjnie tanie ${ }^{66}$. Cegielnia stale poszerzała swój asortyment - w ogłoszeniu z roku 1871 była mowa nie tylko o piecach, różnych rodzajach cegieł i dachówek, ale także o ozdobach ogrodowych i „naczyniach do sztucznego chowu ryb”, czyli o produktach przeznaczonych przede wszystkim dla odbiorców indywidualnych.

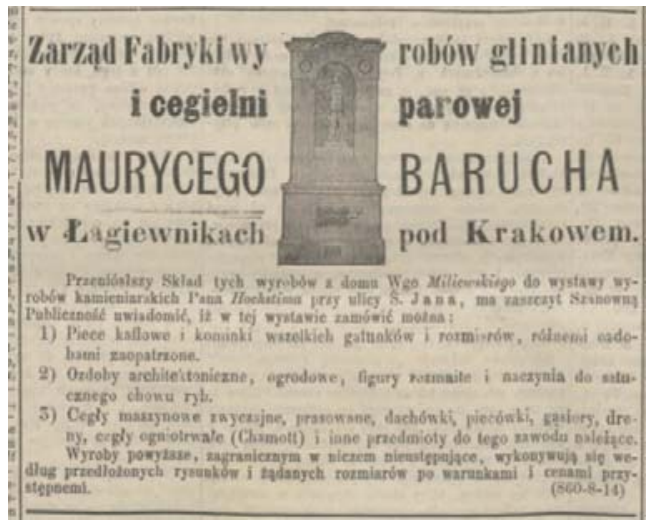

Fot. 11. „CZas"181, 10.08.1871, s. 4.

Produkcję stale ulepszano, poszerzano też asortyment ${ }^{67}$, powiększając na przykład o „nowinki ciepłownicze”, mając przy tym na uwadze nie tylko estetykę produktów, ale również ich wydajność i walory oszczędnościowe.

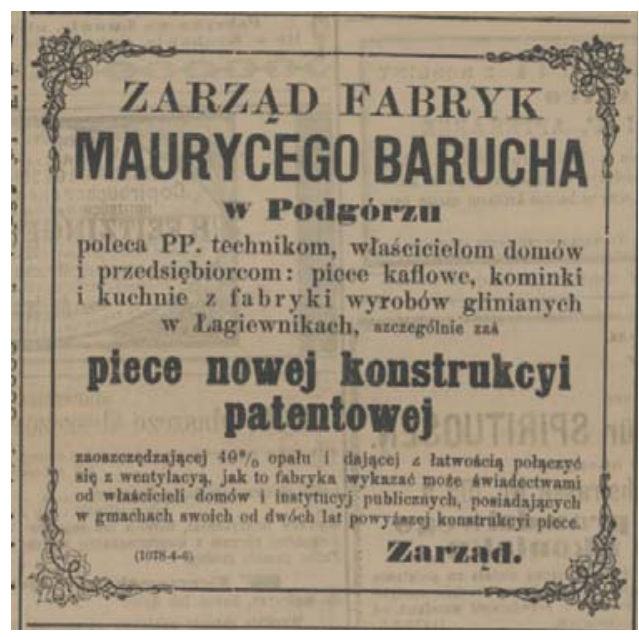

Fot. 12. „Czas"114, 20.05, 1882, s. 6.

${ }^{66}$ Ogłoszenie, „Czas” 153, 7.07.1867, s. 4, za B. Kostuch, 2011, s. 233.

${ }^{67}$ Cegielnia parowa Maurycego Barucha..., NR 164, 20.07.1888, s. 4. 
W roku 1897 reklamowano m.in. „dachówkę szwajcarską patentowaną”68. Asortyment w roku 1899 obejmował piece, kominki, kuchnie, dachówkę żłobkowaną systemu „constans” nadającą się do budynków monumentalnych, a charakteryzującą dużą wytrzymałością, łatwym kryciem i lekkością; cegłe maszynową, ręcznie prasowaną, podwójnie prasowaną i studzienną; cegłę ogniotrwałą zwykłą, klinową, formowaną i płyty ogniotrwałe piekarskie ${ }^{69}$. $\mathrm{Na}$ początku XX w. fabryka produkowała niewielkie partie dachówki szklonej czyli glazurowanej ${ }^{70}$. W r. 1907 w asortymencie znalazły się cegły do sklepień Ludwiga i terakoty budowlane $e^{71}$.

O tym, że wzmianki o renomie produktów baruchowskich poza granicami Galicji nie były pozbawione podstaw, świadczyła notatka „Czasu” o zamówieniu w przedsiębiorstwie pieców i kominków do zamku myśliwskiego arcyksięcia Rudolfa Habsburga w Syhocie Marmaroskim (Marmaros Szyget) - „(...) mimo licznej konkurencyi wiedeńskiej i pesztańskiej”72. Notatkę zamykała skarga $\mathrm{z}$ gatunku „cudze chwalicie, swego nie znacie”: mimo tego, że ceglarstwo i zduństwo pięknie się rozwinęło w Galicji, to jednak władze większych miast galicyjskich i mieszkańcy kronlandu woleli zamawiać wyroby zagraniczne, chociaż „(..) nasze fabryki zarówno co do trwałości materiału, jak i artystycznego wykonania śmiało o lepsze współzawodniczyć mogą".

\section{Wapiennik w Płazie}

W r. 1890 otwarto i poświęcono nową fabrykę w Płazie, dwa kilometry od Chrzanowa. Właścicielami zakładu „Gustaw Baruch i Spółka” byli - Gustaw Baruch i dr Józef [Stanisław] Retinger ${ }^{73}$. Sprawozdanie z otwarcia przedsiębiorstwa opisywało „serce fabryki”, które stanowił wielki, szesnastokomorowy piec pierścieniowy najnowszego systemu (piec wapienny kręgowy typu Hoffmann) oraz inne budynki znajdujące się na terenie przedsiębiorstwa ${ }^{74}$. W ogłoszeniu podkreślano sensowność jej założenia i lokalizacji: bliskość surowca (250 m), jego potwierdzona przez autorytety naukowe doskonała jakość, prawie $100 \%$

${ }^{68}$ Dyrekcja Zakładów fabrycznych firmy „Maurycy Baruch” w Podgórzu, „Czas” 81, 9.04.1898, s. 4; też „Czas”132, 12.06.1898, s. 8.

69 Zarząd fabryki wyrobów glinianych..., „Czas” 86, 15.04.1899, s. 4; „Czas” 97, 28.04.1899, s. 5; „Czas” 108, 13.05.1899, s. 4; „Czas” 118, 26.05.1899, s. 4; inny design ogłoszenia „Czas” 122, 31.05.1899, s. 4; „Czas” 128, 8.06.1899, s. 5; odmienny design „Czas”233, 12.10.1899, s. 4; „Czas” 236, 15.10.1899, s. 5;

70 A. Partridge, 2017a, s.187.

71 Reklama zakładu „Architekt” 1 (1907), za A. Partridge, 2017a, s. 186; inny design „Czas” 102, 3.05.1907, s. 4. Zastosowanie cegieł systemu Ludwiga umożliwiało redukcję wysokości budynku, dachówka była odporna na pożary i wilgoć, patrz Flachgewölbeziegel nach System Ludwig, https://www.technischesmuseum.at/objekt/flachgewoelbeziegel-nach-system-ludwig-um-1915 [dostęp: 21.07.2020].

72 Kronika, „Czas” 258, 8.11.1884, s. 3.

73 Kronika, „Czas”225, 1.10.1890, s. 2; A. Partridge, 2017a, s. 188.

${ }^{74}$ Dział ekonomiczny, „Czas” 228, 4.10.1890, s. 3. [Ringofen nach Hoffmann's System], wynaleziony przez Friedricha Hoffmanna i wystawiony na wystawie paryskiej 1867, trwały, bezpieczny i bardzo oszczędny w zużyciu paliwa, A. Lipp, 1870, s. 133 i n. Friedrich Eduard Hoffmann, [w:] https://de.wikipedia.org/wiki/Friedrich_Eduard_Hoffmann [dostęp: 9.10.2020]. 
wydajność pozyskania wapna, duże moce przerobowe zakładu oraz elastyczność dostosowania się do zamówień. Ostatni akapit omawiał uroczystość poświęcenia zakładu przez proboszcza i podkreślał znaczenie założenia, wymieniając wysoko postawionych gości z urzędu (marszałek powiatu, radca budownictwa, komisarz starostwa) oraz robotników. Uroczystość zakończyła się ucztą w dworze Retingera.

W kolejnym ogłoszeniu o możliwości składania zamówień zastąpiono ekspertyzę wydaną przez lokalny autorytet naukowy (w poprzednim ogłoszeniu był to prof. chemii UJ Karol Olszewski), ekspertyzą wiedeńskiego Muzeum Przemysłowego, pokreślono także możliwość transportu kolejowego.

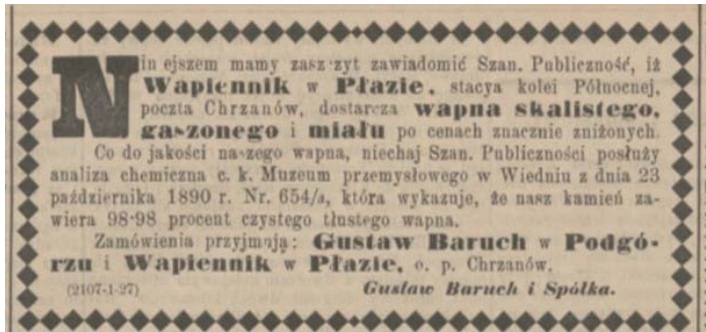

Fot. 13.„(zas" 209, 15.09.1891, s. 4.

W r. 1891 centralne biuro Gustawa Baruch, filia w Krakowie przyjmowało zamówienia na wapno muszlowe produkowane przez fabrykę w Płazie ${ }^{75}$.

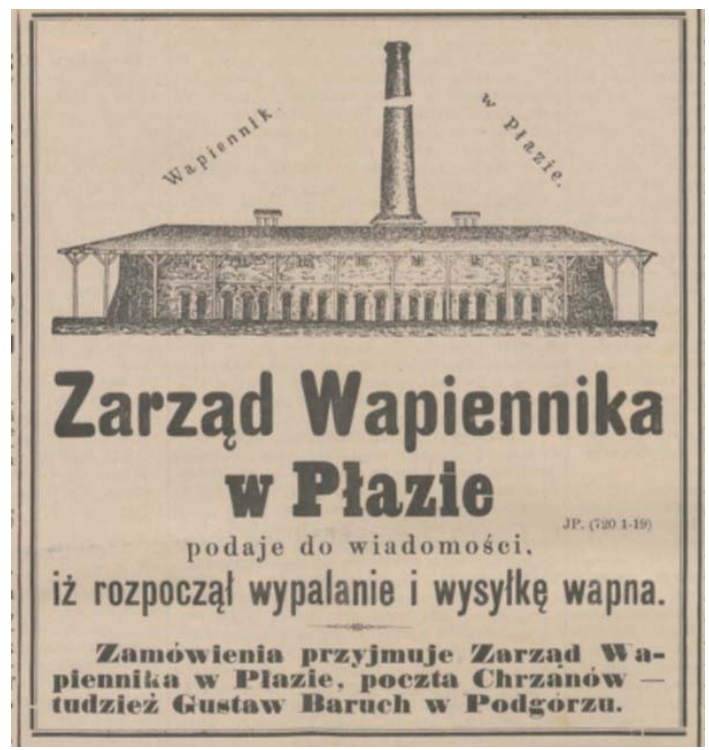

Fot. 14. „Czas" 66, 21.03.1893, s. 4.

${ }^{75}$ Ogłoszenia, NR 28, 28.01.1891, s. 4. 


\section{Podział firmy}

Po śmierci Maurycego w roku 1874 jego synowie, Emil i Gustaw, zawiązali spółkę jawną w celu dalszego prowadzenia firmy ${ }^{76}$. Po śmierci Emila w 1886 współwłaścicielami spółki byli po połowie Gustaw i wdowa po Emilu, Róża, wraz z czworgiem dzieci. Sytuacja zmieniła się w chwili dojścia syna Emila, Karola Włodzimirskiego, do pełnoletności. W r. 1893 we wszystkich trzech dziennikach krakowskich: „Czasie”, „Nowej Reformie” i „Głosie Narodu”, ukazało się poniższe ogłoszenie:

Od roku 1847 istnieje w Podgórzu pod Krakowie firma „Maurycy Baruch” która jest właścicielką młynów parowych w Podgórzu tudzież cegielni i fabryki pieców kaflowych i wyrobów glinianych w Łagiewnikach. Właścicielami tej firmy byli dotychczas w jednej połowie p. Róża z Lordów Włodzimirska i pp. Aleksander, Karol, Emilia i Alfred Włodzimirscy, a w drugiej połowie p. Gustaw Baruch. W ostatnich dniach przeszła własność połowy spółki p. Gustawa Barucha drogą sprzedaży na pp. Aleksandra, Karola, Emilię i Alfreda Włodzimirskich, tak że obecnie jawnymi Spólnikami spółki handlowej pod firmą „Maurycy Baruch”, młyn parowy w Podgórzu i cegielnia parowa w Łagiewnikach” są tylko p. Róża z Lordów Włodzimirska, i pp. Aleksander, Karol, Emilia i Alfred Włodzimirscy, a p. Gustaw Baruch już w spółce tej żadnego więcej udziału nie posiada. Do podpisywania firmy per procura upoważnili spólnicy łącznie p. Jerzego Franciszka Maryewskiego, dyrektora zakładów fabrycznych w Podgórzu i p. Karola Włodzimierskiego. Ponieważ firma: „Maurycy Baruch” jest jedną z najstarszych i najpoważniejszych w kraju, a jedyną $\mathrm{z}$ pierwszych w przemyśle młynarskim i cieszy się uznaniem nie tylko w kraju, ale i za granicą, przeto zmiana zaszła w firmie interesować będzie nie tylko przemysłowców, ale i szerokie koła publiczności ${ }^{77}$.

Od roku 1893 działały wobec tego dwie firmy: młyn, piekarnia i wapiennik Gustawa Barucha oraz firma „Maurycy Baruch” Włodzimirskich, która obejmowała młyny, cegielnię i kaflarnię. Publiczność nie rozróżniała jednak precyzyjnie między tymi dwoma zakładami: i tak w 1896 dziennik „Naprzód” przypominał, że Gustaw prowadził wprawdzie w dalszym ciągu młyn, ale już nie pod firmą „Maurycy Baruch” ${ }^{78}$. Prasa w dalszym ciągu miała kłopoty z istnieniem dwóch przedsiębiorstw: w roku 1897 zawiadamiano, że firma „Maurycy Baruch” zbankrutowała, chociaż zbankrutowało przedsiębiorstwo Gustawa ${ }^{79}$. Dlatego też Włodzimirscy zdecydowanie podkreślali niezależność obu przedsiębiorstw:

Z powodu krążących mylnych pogłosek rodzina Włodzimirskich, jako właścicielka firmy „Maurycy Baruch”, istniejącej od lat 50 w Podgórzu, ma zaszczyt zawiadomić

76 B. Kostuch, 2011, s. 234.

77 Nadesłane, NR 275, 1.12.1893, s. 3; też GN 8 (1893), 4; Kronika, „Czas” 275, 1.12.1893, S. 2.

78 Kronika, „Naprzód” 12, 19.03. 1896, s. 4.

79 Kronika, „Naprzód” 34, 26.08,1897, s. 4. 
P.T. Publiczność, że fabryki jej, t.j. młyny parowe w Podgórzu, cegielnia parowa i fabryki pieców kaflowych w Łagiewnikach nic nie mają wspólnego z firmą p. Gustawa Barucha w Podgórzu, że w jej fabrykach nie zaszła żadna zmiana, lecz tak, jak dotychczas pod tym samym zarządem są prowadzone ${ }^{80}$.

Firma Włodzimirskich broniła się też przed zarzutem nierzetelności i stosowaniem odpowiedzialności zbiorowej, wskazując na zadowolenie wysoko ustawionych klientów:

Zarząd pałaców cesarskich węgierskich nadesłał z Marmaros Sziget uprzejme podziękowanie p. Karolowi Włodzimierskiemu, szefowi znanych zakładów fabrycznych w Podgórzu, istniejących pod firmą Maurycego Barucha. Firma ta od lat 14 zaopatruje w piece kaflowe domy myśliwskie cesarskie, a zarząd ich z dostawy jest jak najzupełniej zadowolony ${ }^{81}$.

\section{Firma „Maurycy Baruch” Włodzimirskich ${ }^{82}$}

Włodzimirscy przejęli przedsiębiorstwo w dobrym stanie. W roku 1894 młyny parowe Barucha były, wraz z zakładami braci Murray, Jakubowskiego, Jarra i browarem Jahna, jedynymi przedsiębiorstwami odwiedzonymi przez wycieczkę przedsiębiorców wiedeńskich hołubionych przez władze miasta ${ }^{83}$. Gości, m.in. ministra handlu hr. Ladislaua Gundakera Wurmbranda, podejmował szef firmy Karol Włodzimirski ${ }^{84}$. Oczekiwał na nich u wejścia do młynów, przedstawił urzędników zakładowych i oprowadził po wszystkich częściach zakładu, wyjaśniając ich przeznaczenie. Minister chwalił zakład jako wielki i racjonalnie prowadzony.

Wysokim poziomem zakładu był zachwycony również starosta podgórski Edward hr. Starzeński w czasie wizytacji w r. 1897:

P. starosta wyraził kilkakrotnie zupełne uznanie dla racyonalnego [!] prowadzenia fabryk, jak również i wzorowego porządku, w nich panującego. Następnie zdał się wraz z p. Włodzimirskim do cegielni parowej w Łagiewnikach, gdzie oglądał gotowe zapasy, zamówione dla kolei państwowej, kościoła św. Krzyża itd. poczem zwiedzał kaflarnię, gdzie był obecnym przy wykonywaniu kafli formowych, a nawet na jednej z nich podpisał się na pamiątkę swojej wizyty. Po dokładnem obejrzeniu kaflarni i w ogóle zakładów hr. St. oświadczył właścicielowi, iż nie spodziewał się, ażeby można znaleźć w Galicyi podobnie dobrze i na wielką skalę prowadzone fabryki ${ }^{85}$.

${ }^{80}$ Zawiadomienie, NR 220, 28.09.1897, s. 3; toż samo, NR 226, 5.10.1897, s. 3; GN 220, 28.09.1897, s. 6.

${ }^{81}$ Kronika, NR 253, 6.11.1897, s. 2.

${ }^{82}$ Kronika, NR 250, 30.10.1896, s. 2.

${ }^{83}$ Kronika, GN 143, 27.06.1894, s. 5; Kronika, „Czas” 145, 29.06.1894, s. 3.

${ }^{84}$ Kronika, GN 144, 28.06.1894, s. 5.

${ }^{85}$ Kronika, NR 250, 30.10.1896, s. 2. 
O asortymencie i przecenach firmy informowały ogłoszenia w dziennikach krakowskich:

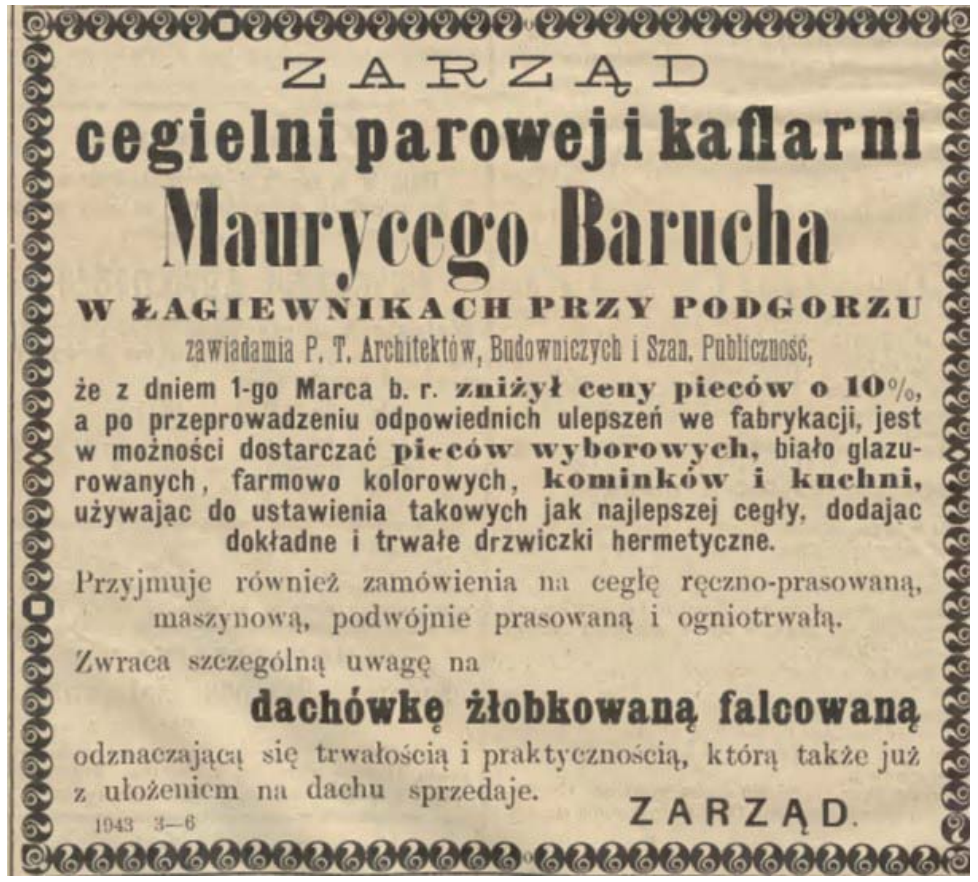

Fot. 15. GN 104, 5.05.1895, s. 10.

W grudniu 1908 roku firma „Maurycy Baruch” obchodziła sześćdziesięciolecie istnienia ${ }^{86}$. Hucznie święcony jubileusz przesłaniał fakt, że w firmie Włodzimirskich działo się coraz gorzej. W r. 1911 „Przemysł ceramiczny” donosił, że zakłady cegielniane w Łagiewnikach przeszły „(...) na akcyjne towarzystwo pod egidą jednego z wiedeńskich banków" ${ }^{87}$. Hermann Feldstein szacował, że wobec słabości finansowej kraju tego rodzaju operacja zapewniała przedsiębiorstwu niezbędny kapitał i mogła sprzyjać jego rozwojowi ${ }^{88}$. W wypadku firmy „Maurycy Baruch” stało się jednak inaczej. W r. 1912 Aleksander i Emilia wystąpili ze spółki i zostali zapewne spłaceni ${ }^{89}$. Pod koniec roku 1912 sprzedano fabrykę kafli, a zaś w r. 1913 przedsiębiorstwo zostało wykreślone z Rejestru Handlowego ${ }^{90}$.

${ }^{86}$ Kronika, NR 517, 9.11. 1908, s. 2; Kronika, NR 515, 6.11. 1908, s. 3.

87 Rozmaitości, „Przemysł ceramiczny” 8, 15.03.1911, s. 96; o unieważnieniu kartelu cegielnianego, patrz Dział ekonomiczny, „Czas” 304, 14.12.1900, s. 2 i n.

${ }^{88}$ H. Feldstein, 1917, s. 65.

89 B. Kostuch, 2011, s. 235.

90 Ibidem. 


\section{Udział w wystawach}

Wypróbowanym sposobem promocji przedsiębiorstw i produkowanych artykułów były nie tylko anonsy w prasie, ale też winiety papierów firmowych, które analizowała obszernie Kamila Follprecht ${ }^{91}$. Umieszczane na nich wizerunki przedsiębiorstw są często jedynym wizualnym świadectwem ich istnienia i ułatwiają identyfikację rozmieszczenia budynków. Promocji służyły też sprawozdania $\mathrm{z}$ różnorakich wystaw, na których przedsiębiorstwa eksponowały swoje wyroby ${ }^{92}$. Sprawozdania charakteryzowały zarówno produkty, jak i gusta publiczności.

Produkty baruchowskie znalazły się wśród eksponatów już od samego początku istnienia zakładu: mąkę prezentowano na krakowskich wystawach rolniczo-przemysłowych w roku 1856 i $1860^{93}$. Według własnego świadectwa, Maurycy w tym czasie brał również udział w targu londyńskim (corn market 1860 ? $^{94}$. Przedsiębiorca uczestniczył też w wystawie rolniczo-przemysłowej w Bielsku w r. $1871^{95}$. Wystawił tam kominki, ozdoby i rurki do drenowania.

Dla sprawozdawcy „Czasu” ważne było podkreślenie, że wyroby „nasze” (tzn. z fabryki Barucha) „(...) mogą konkurować z fabrykami Szląskimi [!] i pruskimi, tak pod względem dobroci materyału, jak wykończenia" ${ }^{96}$. Tego zdania byli najwyraźniej też „obcy” jurorzy: Barucha uhonorowano drugą nagrodą za wyroby z gliny. O międzynarodowej renomie przedsiębiorstwa świadczy także fakt, że Maurycy i Gustaw byli mianowani przez cesarza członkami komisji Światowej Wystawy Powszechnej w Wiedniu 1873: Maurycy jako właściciel fabryki towarów glinianych w Borku, a Gustaw jako właściciel piekarni parowej i dóbr w Wieliczce ${ }^{97}$. Baruch został zastępcą w sekcji VI, przygotowującej ekspozycję krakowską ${ }^{98}$. Gustawa wybrano do sekcji 24., przygotowującej ekspozycję wyrobów z kamienia, gliny i szkła na wystawie rolniczo-przemysłowej w 1877 we Lwowie ${ }^{99}$. Był wielickim delegatem na tę wystawę ${ }^{100}$. Był także członkiem komitetu przygotowującego ekspozycję na wystawę paryską $1878^{101}$, jak również zasiadał w komitecie przygotowującym wystawę przyrodniczo-lekarską w Krakowie w r. $1881^{102}$.

Notatka „Czasu” potwierdzała popularność fabrykatów przedsiębiorstwa i powszechność ich zastosowania w budynkach publicznych. Sprawozdawcy

${ }^{91} \mathrm{~K}$. Follprecht, Krakowskie winiety papierów firmowych, (w druku).

${ }_{92}$ K. Follprecht, Baruchowie, [w:] Encyklopedia Krakowa (w druku).

${ }_{93}$ J. Demel, 1958, s. 50.

${ }_{94}$ M. Baruch, Nadestane, „Czas” 179, 7.08.1860, s. 4.

${ }_{95}$ Gospodarstwo, przemyst $i$ handel, „Czas” 205, 8.09.1871, s, 2.

${ }_{96}$ Gospodarstwo przemyst i handel, „Czas” 212, 17.09.1871, s. 3.

97 Urzędowa Wiener Ztg., „Czas” 37, 16.02.1872, s. 2.

${ }_{98}$ Wystawa Powszechna w Wiedniu, „Czas” 61, 15.03.1872, s. 2-3.

99 Wystawa rolniczo-przemystowa we Lwowie 1877 r. „Czas” 89, 20.04.1877, s. 2; Katalog

krajowej wystawy rolniczej i przemysłowej we Lwowie 1877, 1877, Lwów, s. XXIII.

100 Wystawa rolniczo-przemysłowa we Lwowie 1877 r., „Czas” 89, 20.04.1877, s. 2.

101 Gospodarka, przemyst i handel, „Czas” 95, 27.04.1877.

102 Kronika, „Czas” 4, 6.01.1881, s. 2. 
podkreślali przede wszystkim udogodnienia wprowadzone przez fabrykanta i efektywność nowej konstrukcji:

Oglądaliśmy takie piece $\mathrm{w}$ budynku Towarzystwa wzajemnych ubezpieczeń w Krakowie, gdzie zaniechano ogrzewania sal i biór [!] powietrzem, a wystawiono 22 pieców systemu nowego, które wyrabia fabryka pod firmą Maurycego Barucha w Łagiewnikach za Podgórzem. Również piece tego systemu zaprowadzono w instytucie wychowawczym Urszulanek, w wielu prywatnych mieszkaniach i we Lwowie w gmachu sejmowym. Piece te są stosunkowo małego rozmiaru, dadzą się zastosować z całą dokładnością do objętości lokalu, wymagają palenia raz na dzień i trzymają nie tylko ciepło, ale oraz żar [!] przez cały dzień, a wreszcie zużywają tylko połowę paliwa, jakiego wymagają inne zwykłych systemów piece, dozwalają regulować stopień ciepła $\mathrm{w}$ mieszkaniu podług termometru, czyszczą powietrze, będąc opatrzone wentylatorami, nie wydają z siebie czadu, gdyż płomień nie dochodzi bezpośrednio ścian pieca. Niemniej do starych pieców daje się zastosować przyrząd p. Barucha, wymaga jednak przestawienia ich [!]. P. Gustaw Baruch, właściciel cegielni i fabryki pieców przyczynia się przez to wyrobami swemi do rozwoju przemysłu krajowego i daje zarobek okolicy, gdy dotychczas piece ozdobniejsze sprowadzano do nas zwykle z zagranicy, a co dziwniejsza, że glina surowa wywożona stąd, aby z niej gdzieindziej wypalać kafle i ornamenty budowlane ${ }^{103}$.

Przedsiębiorstwo Gustawa wyróżniono dyplomem honorowym Krakowa $^{104}$. W r. 1883 firma Barucha wzięła udział w wielickiej wystawie rolniczo-przemysłowej, gdzie pokazywała wyroby z gliny i terakoty, m.in. glazurowany kominek artystycznych kształtów ${ }^{105}$. Wyroby firmy zostały uhonorowane złotym medalem ${ }^{106}$.

Obaj bracia weszli z ramienia IPH do komitetu organizacyjnego Wystawy Krajowej organizowanej w 1887 r. w Krakowie ${ }^{107}$. W czasie tej Wystawy Gustaw był sędzią/jurorem w grupie zboża, wyrobów młynarskich oraz maszyn wyrobu krajowego oraz maszyn przemysłowych producentów zagranicznych ${ }^{108}$. Wybrano go do prezentacji ziemiopłodów, a konkretnie zboża ${ }^{109}$. Wystawiał zarówno wyroby mączne, jak i „dobrze znane wyroby tej piekarni”:

103 Kronika, „Czas”256, 9.11.1881, s. 2 (wytłuszczenia HKW).

104 K. Follprecht, Krakowskie winiety.

105 Wystawa rolniczo-przemysłowa w Wieliczce, „Czas” 195, 29.08.1883, s. 2. Katalog wystawy rolniczo przemysłowej $w$ Wieliczce $w$ r. 1883, 1883, Kraków, s. 21 nie wymienia Barucha wśród wystawców.

106 Wystawa rolniczo-przemysłowa $w$ Wieliczce, „Czas” 196, 30.08.1883, s. 2.

107 Kronika, „Czas”276, 2.12.1886, s. 3.

108 Gospodarka, przemyst i handel, „Czas” 105, 18.05.1887, s. 3; Gospodarka, przemysł i handel, „Czas”106, 10.05.1887, s. 3. Kronika, NR 64, 19.03.1887, s. 2; Lista sędziów krajowej wystawy rolniczo-przemysłowej w Krakowie, NR 105, 8. 05.1887, s. 3; Lista sędziów krajowej wystawy rolniczo-przemysłowej w Krakowie, NR 106, 9.05.1887, s. 3; Sędziowie jury wystawy krajowej, „Gazeta Młynarska” 7, 15.07.1887, s. 3.

109 Kronika, NR 63, 18.03. 1887, s. 2. 
chleby i suchary ${ }^{110}$. Został uhonorowany dyplomem za mąkę i pieczywo ${ }^{111}$. Chleb Graham z piekarni Gustawa uzyskał poparcie komisji przemysłowej krakowskiego Towarzystwa Lekarskiego ${ }^{112}$. Medalem srebrnym ministerstwa handlu została nagrodzona wynaleziona przez Gustawa maszyna do wyrobu sucharó $^{113}$. Maszyna była prezentowana na wystawie krajowej w r. 1887 jako sprawdzona i szeroko stosowana ${ }^{114}$. Tak więc Gustaw nie poprzestawał tylko na sprowadzaniu nowoczesnych narzędzi z zagranicy, ale sam eksperymentował i był wynalazcą.

Produkty firmy prezentowano również w dziale materiałów budowlanych. Obszerne sprawozdanie „Czasu” pozwalało poznać gust publiczności, która zachwycała się przede wszystkim wyrobami „historyzującymi”: firma „Maurycy Baruch" wystawiła jeden piec zwykły biały kaflowy i dwa piece wraz z kominkami w ,stylu staroniemieckim, wykonane bardzo gustownie $\mathrm{z}$ ciemnych kafli" ${ }^{115}$. Sprawozdawca nadmieniał, że wzorów do kolorowych kafli dostarczały uczennice seminarium żeńskiego, co świadczyło o współpracy między fabryką a lokalnymi szkołami, zainicjowaną zapewne przez samorząd miejski. Wymieniano również inne produkty baruchowskie - dachówki, dreny i cegły, chwaląc ich jakość. Szczególnie obszerne sprawozdanie z wystawy krakowskiej zamieściła "Nowa Reforma”"16. Produkty podobały się do tego stopnia, że Jan Przybylski z Podgórza, zarządca fabryki Barucha, dostał list pochwalny dla zasłużonych współpracowników za majoliki i wyrób kafli glazurowanych ${ }^{117}$.

Graham baruchowski został wyróżniony brązowym medalem podczas wystawy towarzyszącej zjazdowi lekarzy i przyrodników polskich w Krakowie $\mathrm{w} 1891 \mathrm{r}^{118}$. Graham miał reprezentować wyroby galicyjskie na międzynarodowej wystawie Czerwonego Krzyża w Lipsku w $1892 \mathrm{r}^{119}$. W tym samym roku Gustaw wszedł w skład krakowskiego komitetu lwowskiej wystawy przemysłu budowlanego i został mianowany jednym z sędziów w sekcji I budownictwa ${ }^{120}$. Jednak po podziale przedsiębiorstwa ani firma Włodzimirskich „Maurycy Baruch", ani młyn Gustawa nie wzięły udziału w wystawie krajowej we Lwowie w r. 1894, co zostało zauważone przez sprawozdawców „Głosu Narodu” ${ }^{21}$. Ponadto młyny i cegielnia baruchowska nie zostały wymienione w opracowaniu

110 Kronika, „Czas” 211, 16.09.1887, s. 2.

111 Wystawa krajowa. Pawilon główny, „Czas”212, 17.09.1887, s. 2; Wystawa krajowa, NR 212, 17.09.1887, s. 2; K. Follprecht, Krakowskie winiety.

112 Dział ekonomiczny, NR 134, 15.06.1887, s. 3; Nadesłane, NR 204-205, 8.09.1887, s. 5.

113 Wystawa krajowa, NR 229, 7.10.1887, s. 2

114 Sprawozdanie $z$ Wystawy VI, NR 256, 9.11. 1887, s. 1

115 Wystawa krajowa. Pawilon główny, „Czas” 228, 6.10.1887, s. 3.

116 Sprawozdanie z wystawy VII, NR 258, 11.11. 1887, s. 2. Patrz Aneks 1.

117 Wystawa krajowa, NR 222, 29.09.1887, s. 2.

118 Premiowanie wystawców, NR 164, 22.07.1891, s. 2.

119 Kronika, NR 137, 19.06.1891, s. 2.

120 Dział ekonomiczny, „Czas”92, 22.04.1892, s. 3; Katalog wystawa przemysłu budowlanego we Lwowie 1892, 1892, s. XIII i XX.

121 Przemyst galicyjski na Wystawie, Młynarstwo, GN 198, 1.09.1894, s. 3; Katalog Powszechnej Wystawy Krajowej we Lwowie roku 1894, 1894, s. 53-63. 
na temat przemysłu fabrycznego umieszczanego w Katalogu wystawy ${ }^{122}$, Baruchów zabrakło też na ekspozycji przemysłu ceramicznego ${ }^{123}$. Natomiast piece baruchowskie wyeksponowano na wystawie przyrodniczo-lekarskiej w r. 1900, zorganizowanej przy okazji zjazdu lekarskiego ${ }^{124}$.

Uczestnictwo w wystawach krajowych i zagranicznych i otrzymywane wyróżnienia potwierdzają ponadlokalną renomę produktów przedsiębiorstwa. Wzmianki prasowe wskazują na to, że były dobrej jakości i oszczędne w użyciu oraz trafiały w gust publiczności. Szeroką paletę produktów adresowano zarówno do bogatych, jak i do mniej zamożnych. Ponieważ niektóre modele były bardzo kosztowne, więc uchodziły za luksus i były obiektami prestiżowymi.

\section{Stosunki w firmie}

W r. 1886 inspektor przemysłowy Arnulf Navratil wystawił młynom i piekarniom baruchowskim dobre świadectwo. Stwierdził, że pod względem ogniotrwałości i bezpieczeństwa życia robotników jako jedyne w Galicji (!) „(...) urządzone są w sposób pod każdym względem nienaganny” ${ }^{125}$. Fakt ten zasługuje na podkreślenie bowiem warunki pracy w cegielniach galicyjskich, podobnie jak warunki mieszkaniowe pracujących w nich robotników były nędzne i - w porównaniu $\mathrm{z}$ innymi zakładami, najgorsze w kronlandzie ${ }^{126}$. W roku 1891, wobec panującej niezwykłej drożyzny, Baruchowie, jako pierwsi kapitaliści, podwyższyli pensję robotnikom o prawie $10 \%{ }^{127}$.

$\mathrm{Z}$ drugiej strony w roku 1893 donoszono, że robotnicy muszą w piekarni pracować przez 12 godzin bez przerwy, a w niedziele nawet 18 godzin ${ }^{128}$. W odpowiedzi na krytyczne notatki prasowe, nienazwane przez dziennik strony, zapewne związane $\mathrm{z}$ Włodzimirskimi, prosiły o zaznaczenie, że wyzyskujący robotników młyn Barucha należał do Gustawa, natomiast młyny pod firmą „Maurycy Baruch” przestrzegały spoczynku niedzielnego ${ }^{129}$. W roku 1894 wskazywano na to, że dwunastogodzinny dzień pracy m.in. w cegielni Barucha należy do chlubnych wyjątków, bowiem w większości cegielni pracuje się jeszcze dłużej ${ }^{130}$. Pod skargą na urągające zdrowiu warunki w przedsiębiorstwach Włodzimirskich podpisało się jednak aż 50 robotników cegielni ${ }^{131}$. Aby zakończyć strajk w cegielni, obiecano podwyższyć im płacę ${ }^{132}$.

\footnotetext{
122 B. Pawlewski, 1896, s. 41 i n oraz 54 i n.

123 Katalog Powszechnej Wystawy Krajowej, 1896, s. 70-74.

$124 Z$ wystawy przyrodniczo lekarskiej IV, NR 176, 4.08.1900, s. 2.

125 Korespondecya „Nowej Reformy”, NR 101, 4.05.1886, s. 2.

126 M.A. Lipszyc, 1901, s. 47.

127 Kronika, NR 272, 27.11.1891, s. 2.

128 Ze stowarzyszeń i zgromadzeń, „Naprzód” 15, 4.08.1893, s. 3; Z warsztatów i fabryk, „Naprzód”21, 24.05.1895, s. 4.

129 Podgórze, „Naprzód” 12, 19.03.1896, s. 4.

130 Strajk ceglarzy, „Naprzód” 11, 1.06.1894, s. 3.

131 Kronika, „Naprzód” 26, 27.06.1895, s. 3.

132 Ze stowarzyszeń i zgromadzeń, „Naprzód” 12, 15.06.1894, s. 4.
} 
W roku 1907 w Centralnym Związku Galicyjskiego Przemysłu Fabrycznego we Lwowie, organizacji pracodawców, utworzono sekcję kaflarską ${ }^{133}$. Prowadzono pertraktacje $z$ organizacją robotniczą na temat podwyżek i polepszenia warunków pracy oraz zawarto ugodę na trzy lata. Obowiązywała w firmie „Maurycy Baruch”, u Józefa Niedźwiedzkiego, Jakóba Horowitza i Stefana Hollingera. Także i pod tym względem firma należała do awangardy galicyjskiej.

Tak więc, jeżeli brać pod uwagę tutejsze warunki pracy, robotnikom nie działo się w firmie najgorzej. W drugiej połowie XIX w. wypracowano narratyw popularyzujący działalność przedsiębiorstwa przez podkreślenie przywiązania i lojalności osób w nim zatrudnionych, wdzięcznych za zapewnienie im pracy. Agnieszka Partridge przytacza cytat z „Czasu” charakteryzujący patriarchalny stosunek właścicieli zakładów do robotników oraz wskazujący na ich serdeczność, „szczerą pieczołowitość o los”, opiekuńczą rękę i ojcowską opiekę ${ }^{134}$. „Nowa Reforma” opisywała serdeczne stosunki panujące między robotnikami a chlebodawcami, co wpływało na pracowniczą wierność; kilka wzmianek wymienia zatrudnionych, którzy przez długie lata pracowali w firmie ${ }^{135}$. I tak w r. 1887 urządzono Eliaszowi Goldgardowi, zawiadowcy magazynów, „(...) jubileusz ćwierćwiekowej pracy w zakładzie” ${ }^{136}$. Natomiast w r. 1895 zarząd fabryki wpłynął na decyzję cesarza, który robotnikowi Jerzemu Smajce, pracującemu 49 lat w młynie parowym Gustawa Barucha w Podgórzu, przyznał - w uznaniu jego wieloletniej służby - srebrny krzyż zasługi, co uczczono w odpowiedni sposób:

Wczoraj w jednej z sal fabrycznych wobec licznie zgromadzonych robotników i zaproszonych gości starosta wielicki p. Szczerbiński, wręczył Smajce nadesłany mu krzyż, przyczem podniósł doniosłość uznania wytrwałej i uczciwej pracy. Przemawiał również p. Gustaw Baruch, który zachęcał współpracowników swoich do naśladowania Smajki. Po urzędowym akcie pp. Baruchowie [czy Gustaw i Juliusz?] podejmowali proszonych gości i robotników ${ }^{137}$.

Robotnicy firmy Gustawa należeli do Zakładu Ubezpieczenia Robotników od Wypadków dla Galicji i Bukowiny: Kazimierz Szmajek, starszy młynarz w młynie parowym p. Gustawa Barucha, został wybranym z grupy reprezentantów ubezpieczonych do zarządu ${ }^{138}$.

133 Dział ekonomiczny, NR 153, 3.04.1907, s. 3.

134 „Czas” 232 (1895) za A. Partridge, 2017a, s. 186.

135 N.p. Maurycy Wolff, ajent fabryki Barucha, Kronika, „Czas” 215, 21.09.1869, s. 2; długoletni kierownik piekarni Barucha, Feliks Złamał, Kronika, NR 292, 22.12.1898, s. 2; stróż przy podgórskim młynie Barucha, Piotr Budkiewicz, Kronika, NR 398, 30.08.1908, s. 1; Henryk Tuchfeld, NR 450, 1.10.1908, s. 2; nekrolog, „Czas”244, 1.10.1908, s. 2. Złamał założył w r. 1899 własną piekarnię, Kronika, „Czas” 77, 5.04.1899, s. 2.

136 Kronika, NR 218, 24.09. 1887, s. 2.

137 Kronika, NR 42, 20.02. 1895, s. 2; Kronika, NR 86, 14.04.1896, s. 2.

138 Kronika, NR 84, 11.04.1896, s. 2; GN 85, 12.04.1896, s. 9. 
Również w przedsiębiorstwie Włodzimirskich miała panować rodzinna atmosfera (pisał o tym nawet „Naprzód”, dziennik bardzo krytycznie nastawiony do kapitalistów! ${ }^{139}$. Natomiast „Czas” obszernie relacjonował starannie wyreżyserowaną uroczystość poświęcenia sztandaru ${ }^{140}$. Przy tej okazji wymieniano wszystkich uczestniczących w uroczystości - reprezentujących wojsko, IPH, uniwersytet, duchowieństwo i władze cywilne.

W r. 1907 obchodzono jubileusz czterdziestolecia pracy werkmistrza - Mateusza Snatzkiego, zarządzającego zakładami „Maurycy Baruch” w Podgó$\mathrm{rzu}^{141}$. Firma urządziła ucztę w sławnej restauracji Hawełki w Rynku Głównym. Po stosownych przemówieniach dyrektora fabryk firmy, burmistrza i posła Franciszka Maryewskiego, Snatzki otrzymał złoty zegarek i wspólną fotografię. Życzenia składali urzędnicy: Holenderski, Nyczek i Śmiałek.

Następny jubileusz obchodzono rok później, w r. 1908:

P. Maryewski (...) będzie w dniu jutrzejszym święcił 40-letni jubileusz swojej zawodowej pracy, odbytej w zakładach przemysłowych firmy Maurycy Baruch w Podgórzu, gdzie od 40 lat był urzędnikiem, a od 20 dyrektorem. Równocześnie z tą uroczystością łączy się 60 rocznica istnienia zakładów przemysłowych firmy Barucha.

Uroczystość więc jutrzejsza będzie w całem słowa znaczeniu poważnym aktem hołdu długoletniej pracy tak właścicieli firmy, jak i jubilata kierownika, p. Maryewskiego. Inicyatywa obchodu jubileuszu wyszła od właściciela firmy p. Włodzimierskiego $^{142}$.

Serdeczny stosunek chlebodawców do robotników manifestował się także w działaniach filantropijnych: np. zaopiekowali się „szczodrze” sześcioma sierotami po Rochu Rzepeckim, zmarłym urzędniku administracji młynów ${ }^{143}$. Właściciele angażowali się również w akcje ratownicze. „Nowa Reforma” donosiła o uczestnictwie właściciela młyna w walce z ogromnym pożarem w Podgórzu: przerwał pracę w młynach i wysłał wszystkich ludzi do gaszenia ognia ${ }^{144}$. W roku 1886 „Baruch podgórski” jako jedyny przedsiębiorca przysłał ludzi „z beczką” do gaszenia pożaru fabryki Zieleniewskiego przy ul. św. Krzyża i św. Marka ${ }^{145}$. W roku 1888 z własnej inicjatywy uczestniczył w akcji ratowania dotkniętych powodzią, oddając do dyspozycji kilka wozów ${ }^{146}$.

Tak więc przedsiębiorstwa baruchowskie zapewniały zatrudnionym nie tylko pracę i utrzymanie, ale także troszczyły się o nich - oczywiście według ówczesnych standardów i przy zachowaniu obowiązujących dystansów

139 Kronika, „Naprzód” 27.06.1895, s. 3.

140 Kronika, „Czas” 144, 26.06.1895, s. 2. (patrz Aneks 2.)

141 Kronika, NR 57, 5.02.1907, s. 2; Kronika, NR 60, 6.02.1907, s. 2.

142 Kronika, NR 515, 7.11.1908, s. 3; Kronika, NR 517, 9.11.1908, s. 2; Kronika, „Czas” 256, 6.11.1908, s. 1 .

${ }_{143}$ Podziękowanie, „Czas” 239, 19.10.1876, s. 3.

144 Kronika, NR 94, 25.04.1885, s. 2.

145 Kronika, NR 246, 27.10.1886, s. 2; Kronika, NR 246-247, 28.10.1886, s. 4.

146 Wylew Wisty, NR 62, 15.03.1888, s, 2. 
społecznych. Już samo utworzenie stanowisk pracy rozumiano jako działalność dla dobra ogólnego i spełnienie patriotycznego obowiązku. Dalsze akcje na rzecz pracowników były dobrowolnymi działaniami manifestującymi opiekuńczość patriarchów-pracodawców i oddawały feudalny charakter panujących stosunków społecznych.

Kryzys w przedsiębiorstwie przełożył się także na relacje międzyludzkie. Jego zapowiedzią był fakt, że w roku 1902 Włodzimirscy obniżyli robotnikom wynagrodzenie $^{147}$. W r. 1912 „Naprzód” relacjonował z goryczą, bez cienia sympatii dla „dobrych kapitalistów”, zwinięcie przedsiębiorstwa:

Dola robotnicza. Znaną była w Podgórzu firma Baruch, posiadająca młyn, kaflarnię i cegielnie. Długoletnim kierownikiem firmy był do 1 . kwietnia 1911 r. burmistrz Maryewski. Robotnicy zatrudnieni w tej firmie należeli do fabrycznej Kasy chorych, której fundusz rezerwowy po rozwiązaniu Kasy w lecie 1911 r. uchwalono w myśl statutu rozdać między członków Kasy, przyczem pokrzywdzono robotników z cegielni, sprzedanej przed rozwiązaniem kasy. Następnie sprzedała firma kaflarnię, a obecnie wypowiedziano pracę robotnikom zatrudnionym w młynie. 57 ludzi wyrzuca się na bruk, wśród nich ludzi, którzy pracowali w firmie bez przerwy po lat 40, a 27 osób zatrudnionych dłużej niż po 20 lat. Obecny właściciel młyna p. Włodzimirski, puszczający bez skrupułu grosz wyciśnięty z krwawej pracy robotników, zamierza obecnie wyrzucić 57 robotników i urzędników, z których większość sterała swe siły w jego młynie i niełatwo znajdzie teraz pracę gdzieindziej [!]. P. Włodzimirski jako kapitalista nie jest sentymentalny, wycisnął z robotników ich siły, a teraz jak zużytą cytrynę rzuca na bruk. Weterani pracy, inwalidzi baruchowscy zostaną nędzarzami; może im przyjdzie wyciągać rękę, gdy p. Włodzimirski będzie hulał w Wiedniu i Paryżu ${ }^{148}$.

W prasie zamieszczono ogłoszenia świadczące o tym, że „opiekuńczość” zarządzających firmą nie była całkowicie szczera.

\section{Firma Maurycy Baruch w Podgórzu podaje do wiademotel, to Pasowle Dawld Marko* wlez, Szymon Pelezer I Zygmant Rosobberg prae-
stall byd arzednikaml Firmy.}

Fot. 16. NR 147, 30.03.1912, s. 4.

147 Kronika, „Naprzód” 34, 4.02.1902, s. 2.

148 Kronika, „Naprzód” 41, 21.02.1912, s. 4. 


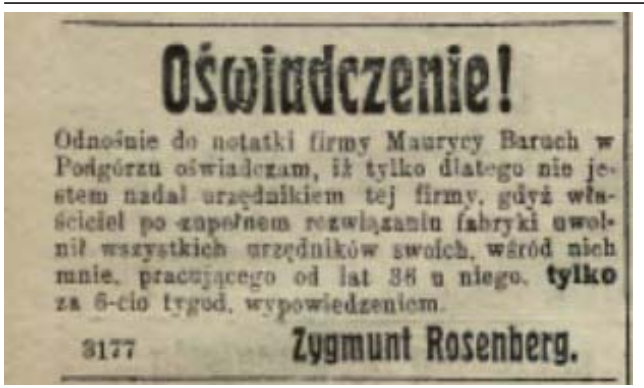

Fot. 17. NR 151, 2.04.1912, s. 6.

\section{Przyczyny upadku}

Omawiając rozwój młynarstwa w Galicji, Tadeusz Rutkowski wskazywał, że jego złoty wiek trwał przez lata sześćdziesiąte i skończył się w r. $1869^{149}$. Wiązało się to z nieurodzajem na Węgrzech, co zwiększyło popyt na mąki galicyjskie. Wojna prusko-austriacka wpłynęła na wzrost zamówień wojskowych i eksport do regionów zniszczonych działaniami wojennymi w Czechach i na Morawach. Powstało w tym czasie wiele przedsiębiorstw młynarskich, które w kolejnych latach ostro ze sobą konkurowały, tym bardziej że zwiększyły się importy zboża amerykańskiego, rosyjskiego i rumuńskiego do młynów położonych bardziej centralnie, np. na Wegrzech ${ }^{150}$. Ujemny wpływ miała również polityka podatkowa państwa - korzystna dla młynów węgierskich, dały się też odczuć trudności w uzyskaniu kredytu oraz niekorzystne taryfy kolejowe. W początku lat osiemdziesiątych Niemcy wprowadziły cła ochronne na dowożoną z zagranicy mąkę. Rutkowski pisał w r. 1888, że zachodnie części Galicji wzdłuż linii kolejowej były zarzucane bajecznie tanią węgierską mąką ${ }^{151}$. Cenę kalkulowano od razu ze stratą, aby tylko zdobyć rynek i wyprzeć młynarstwo krajowe.

Dała się też zauważyć zależność między sukcesem przedsiębiorstwa a zamówieniami publicznymi i wojskowymi ${ }^{152}$. W r. 1885 wojskowość przestała zamawiać mąkę żytnią galicyjską, jako zanieczyszczoną sporyszem, a zaczęła sprowadzać mąkę z Węgier ${ }^{153}$. Interwencje krakowskiej IPH, m.in. Gustawa i Emila Barucha, były nieskuteczne. Gustaw Baruch nawet sprowadził do zbadania z Węgier próbkę żyta, które okazało się w jeszcze większym procencie

149 T. Rutkowski, 1886, s. 21-23 i 31; A. Lipp, 1870, s. 28; Ze statystyki młynarstwa, „Gazeta Młynarska” 1, 26.01.1887, s. 4.

150 Zboże rosyjskie było bardziej wartościowe i czyste, A. Lipp, 1870, s. 30.

151 T. Rutkowski, 1886, s. 43.

152 Przemysł krajowy a dostawy publiczne, „Przemysłowiec „7, 12.10.1903, s. 1-2; T. Kargol, 2003, s. 138 i n. O roli wojska w zamówieniach zboża patrz Dział ekonomiczny, „Czas” 24, 30.01.1890, s. 2.

153 Dział ekonomiczny, NR 274, 29.11.1885, s. 4; Dostawy żyta dla wojska w Galicyi, NR 282, 10.12.1885, s. 2; Dział ekonomiczny, NR 79, 7.04. 1886, s. 3; Dział ekonomiczny, NR 256, 9.11. 1887, s. 3 . 
zanieczyszczone sporyszem ${ }^{154}$. Omijanie firmy Barucha przy zamówieniach wojskowych/rządowych było podnoszone przez Arnolda Rapaporta w czasie obrad Koła Polskiego ${ }^{155}$.

Niebagatelną rolę odgrywała też miejscowa konkurencja. Często siły fachowe, wykształcone w przedsiębiorstwie, usamodzielniały się i prowadziły pokrewną działalność ${ }^{156}$. Od samego początku firma Maurycego Barucha była oczerniania przez przedstawicieli młynów tenczyńskich ${ }^{157}$. Konkurentem Barucha stał się jego wcześniejszy wspólnik, Maurycy Władysław [Moritz Ladislaus] Koliszer, który organizował młyn podgórski i kierował nim na spółkę $\mathrm{z}$ Baruchem do r. 1857, a potem przeszedł do Tenczynka ${ }^{158}$. Konkurencja podszywała się czasem pod firmę: w r. 1887 pojawił się chleb z fałszowaną banderolą - marką ochronną ${ }^{159}$.

W roku 1888 odbyła się w Krakowie rozprawa przeciw Konstantemu hr. Reyowi, byłemu właścicielowi młynów królewskich, oskarżonemu o trzy zbrodnie oszczerstwa. Rey miał donieść ministerstwu wojny, iż w młynie Barucha na Podgórzu przy mieleniu zboża na mąkę dla wojska dziać się miały nadużycia, i że tenże p. Baruch przekupywać miał urzędników wojskowych ${ }^{160}$. Przypuszczalnie właśnie to pomówienie wpłynęło na wycofanie zamówień wojskowych. Śledztwo wykazało, że młyny baruchowskie zasługiwały na najlepszą reputację, były firmą czystą i nieposzlakowaną. W sprawie Barucha w Bośni (dostawy dla wojska?) interpelowali do ministra obrony krajowej w izbie poselskiej [Anton?] Tausche i [Josef Alfred?] Heilsberg ${ }^{161}$.

Niestety, nie udało mi się odnaleźć bliższych informacji o procesie o obrazę czci, który w r. 1889 Gustaw wytoczył Wiktorowi Placzkowi i Leonowi Langerowi z Podgórza ${ }^{162}$. Przypuszczalnie chodziło o pomówienie o nieuzasadnione pobieranie wynagrodzenia za czynności wchodzące w zakres bezpłatnie sprawowanej funkcji radcy miejskiego. Zamieszczenie ogłoszenia w prasie wskazuje na metody, do jakich sięgano, chcąc pozbawić dobrego imienia konkurentów, a może jedynie znienawidzonych członków lokalnych elit.

Obaj oskarżyciele zostali uznani za winnych pomówienia i skazani na 10 dni aresztu, ewentualnie 50 złr. grzywny. W tym samym czasie „Nowa Reforma” opublikowała krótką wzmiankę chwalącą dobrą jakość dachówek falcowanych firmy Maurycego Barucha, które wytrzymały nawiedzające miasto burze gradowe $\mathrm{e}^{163}$.

${ }^{154}$ Gospodarstwo handel i przemyst, „Czas” 81, 9.04.1886, s. 3.

155 Korespondencya „Nowej Reformy”, NR 262, 13.11.1896, s. 1.

156 Np. Nadmlynarz, „Gazeta Młynarska” 1, 26.01.1887, s. 8.

157 M. Baruch, Nadestane, „Czas” 179, 7.08.1860, s. 4; Sprawy sadowe. Proces Knausa o oszustwo, „Czas” 258, 13.11.1866, s. 3.

158 M.W. Koliszer, Nadesłane, „Czas” 182, 10.08.1860, s. 4.

159 Kronika, „Czas” 28, 5.02.1887, s. 2.

${ }^{160}$ Kronika, NR 17, 21.01.1888, s. 3; Zbrodnia oszczerstwa, „Gazeta Młynarska” 1, 10.02.1888, s. 3 i n.

161 Wiedeń 10 kwietnia, NR 83, 11.04.1888, s. 5.

${ }^{162}$ Kronika, NR 102, 3.05.1890. s. 2.

${ }^{163}$ Kronika, NR 111, 15.05.1890, s. 3. 


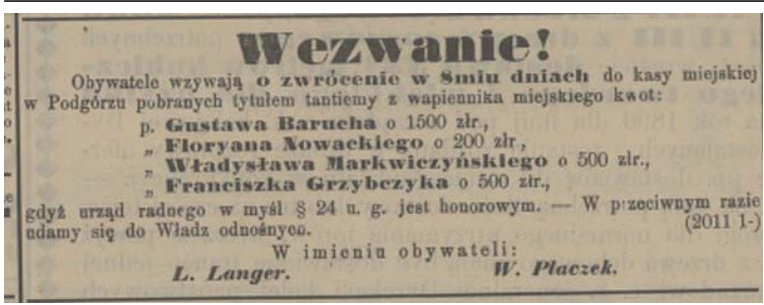

Fot. 18. „Cas"186, 15.08.1889, s. 6.

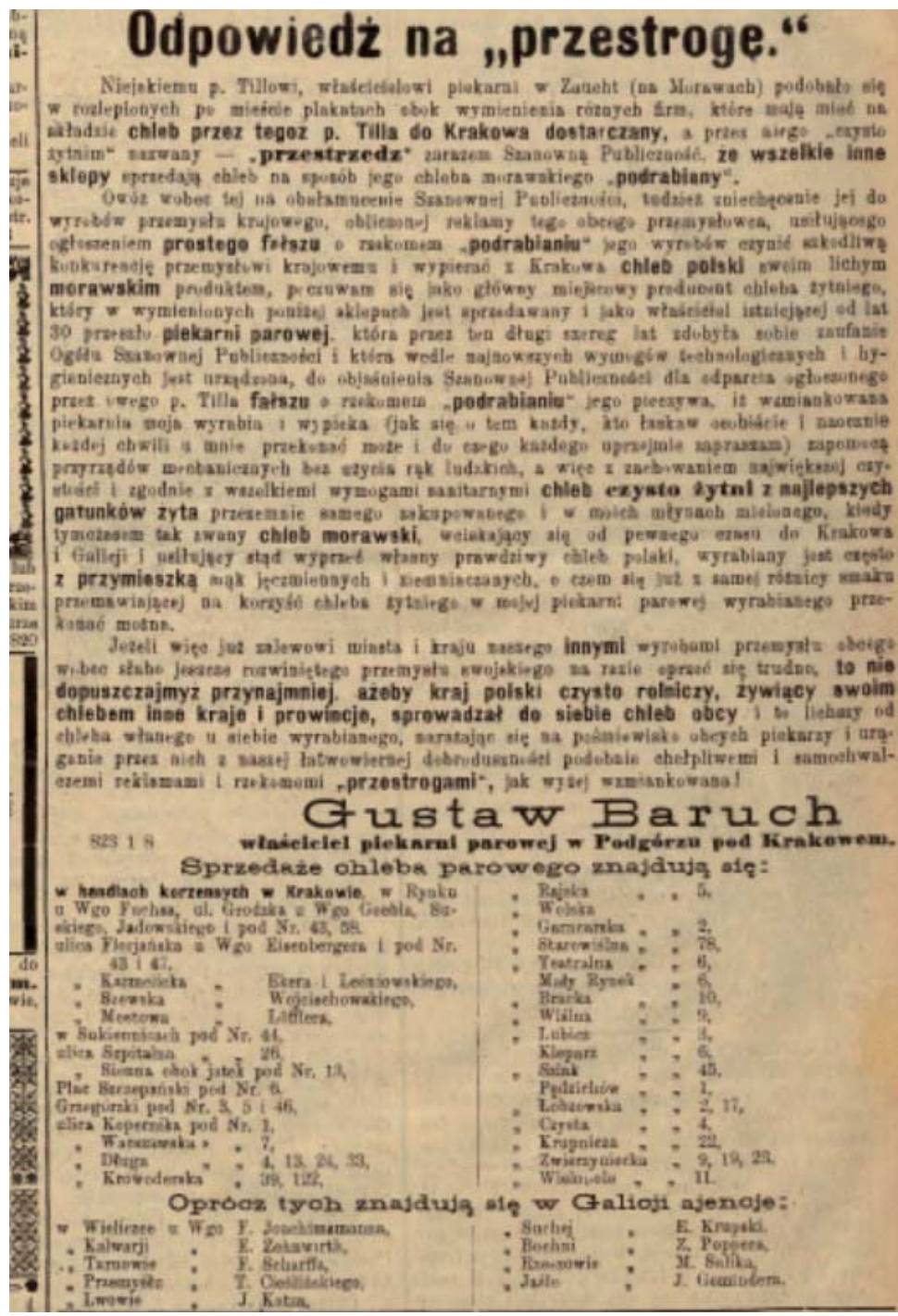

Fot. 19. GN 156 (1894), s. 8; 158 (1894), s. 12; 160 (1894), s. 8; 215 (1894), s. 8; 232 (1894), s. 8. 
Pomówienia jednak nie ustały. I tak „Głos Narodu” donosił w marcu 1894 roku o pogłoskach rozchodzących się Krakowie, że młyny Baruchowskie nie mielą zboża, ale tylko sprzedają pod swoją firmą „mąkę z gipsem mieszaną jakiegoś żyda [!] pesztańskiego" ${ }^{164}$. Konkurencja morawska, którą Gustaw chciał zwalczać piekąc „galicyjski” chleb żytni, również nie zasypywała gruszek w popiele, o czym świadczy poniższe ogłoszenie (Il. 19) ${ }^{165}$. Konkurent Till z Zaucht zarzucał Gustawowi, że baruchowski chleb żytni nie był produktem oryginalnym, a jedynie podróbką chleba morawskiego. Gustaw bronił się, wskazując na higieniczną produkcję i jakość wyrobu, podczas gdy chleb eksportowany z Moraw miał być wyrabiany ręcznie i zawierał liczne przymieszki. Jednocześnie Gustaw przestrzegał przed sprowadzeniem obcego chleba do kraju rolniczego, który „swoim rodzimym” chlebem żywił inne kraje i prowincje.

Ustały nie tylko zamówienia wojskowe. W latach 1894 i 1895 gmina żydowska, która zwykle zamawiała mąkę w młynie Barucha, odrzuciła jego ofertę. Uznała, że mąka z młyna Hirscha Landaua (młyn bieńczycki) była lepsza ${ }^{166}$. Tak więc nie konwersja Gustawa (1885) stała się przyczyną odrzucenia jego oferty, ale pojawienie się konkurenta, będącego wiceprezydentem gminy wyznaniowej. Oferta Landaua miała być tańsza, co jednak okazało się niezgodne z rzeczywistością. Artykuły Chaima Reichenbergera w „Sprawiedliwości Die Gerechtigkeit” piętnowały postępowanie Landaua, który w końcu zrezygnował z przywileju dostarczania macówki ${ }^{167}$. W roku 1897 gmina postanowiła zakupić zboże i zmielić je ponownie w młynie Barucha, jednak młyn nie należał już do Gustawa, ale do przedsiębiorców chasydzkich. Trudno powiedzieć, czy istniał jakiś związek między sprzedażą młyna a wyborem dyrektora zakładów baruchowskich, Franciszka Maryewskiego, na burmistrza miasta Podgó$\operatorname{rza}(1900)^{168}$.

Kryzys nie ominął też cegielni i kaflarni. Na wiosnę r. 1900 krakowska IPH donosiła o tak słabym ruchu budowlanym, że cegielnie pracowały na niewielkich obrotach, co prowadziło do bankructw słabszych przedsiębiorstw ${ }^{169}$. W r. 1903 donoszono o rozpaczliwej sytuacji przemysłu budowlanego w całej Galicji ${ }^{170}$. Jednym z powodów była ofensywa obcych fabryk, które skierowały do Galicji swych agentów „(...) wciskających dachówkę wiedeńską, czeską

164 Odpowiedzi redakcyi, GN 57, 11.03.1894, s. 10

165 Odpowiedź na „przestrogę, GN 156 (1894), s. 8, GN 158 (1894), 12; GN 160 (1894), GN 215 (1894), GN 232 (1894).

166 Eine ofene Ostermehl-Offerte, SG 4, 15.02.1895, s. 3; Żydowskie burdy, GN 131, 12.06. 1897, s. 5.

167 Das Ostermehl 1897, SG 3, 1.02.1897, s. 5 i n.; Sprawy sądowe, „Czas”133, 13.06.1897, s. 2 i n.; „Czas” 344 15.06.1897, s. 2; „Czas” 135, 16.06.1897, s. 1 i n. Macówka była koszerną mąką robioną z starannie wybranych ziaren, patrz M.M. Faierstein, Passover, [w:] https://yivoencyclopedia.org/article.aspx/Passover (25.01.2021)

168 Kronika, „Czas” 51, 27.02.1900, s. 2.

169 Bericht des Gewerbeinspektors 1898, s. 369, cyt. za M. Lipszyc, 1901, s. 54; K. Rolle, Położenie przemysłu ceramicznego w Galicyi w r. 1902, „Przemysł Ceramiczny”, 1.01.1903, s. 2-5.

170 Położenie ruchu budowlanego Galicji, SG 2, 28.01.1903, s. 2-3. 
i wszystkie inne z wykluczeniem krajowej"171. Już w samych Łagiewnikach istniało kilka konkurujących z sobą cegielni ${ }^{172}$. Do trudności krakowskiej branży przyczyniła się zapewne konkurencja lwowska. W roku 1904 kierownik fabryki kafli, Maurycy Silbermann, odszedł do znanej lwowskiej firmy budowlanej Jana Lewińskiego. W roku 1909 na łamach „Głosu Narodu” ukazał się artykuł krytykujący jakość cegły łagiewnickiej: miała ona być wybrakowana ${ }^{173}$. Ponadto w r. 1911 pojawiło się nowe zagrożenie w postaci konkurencji „przez miedzę", bowiem na sąsiadujących gruntach planowano budowę kolejnej olbrzymiej cegielni ${ }^{174}$.

\section{Podsumowanie}

Wobec tych wszystkich niesprzyjających okoliczności sprzedaż interesu wydawała się aktem racjonalnym. Wprawdzie historia firm baruchowskich odpowiadała przytoczonej na początku maksymie o dziadzie, synu i wnuku, ale wydaje się, że upadek firmy spowodowany był nie tyle brakiem zainteresowania i rozrzutnością wnuka, co raczej ogólnym marazmem gospodarczym i bezlitosną walką konkurencyjną. Zakłady baruchowskie pozostały przez cały okres istnienia małymi przedsiębiorstwami rodzinnymi, podczas gdy przetrwanie zapewniało raczej wejście w skład towarzystw akcyjnych czy karteli i dostosowanie produkcji do chłonności rynku imperialnego. Jednak „przygoda kartelowa” Gustawa Barucha i przekształcenie firmy „Maurycy Baruch” w towarzystwo akcyjne świadczy o tym, że i w tym wypadku sukces nie był pewny.

Dalszych badań wymaga stosunek gminy wyznaniowej do rodziny Baruchów. Wiadomo, że Maurycy był z zarządem gminy skonfliktowany, zaś na łożu śmierci przeszedł na luteranizm (1874). Emil już w r. 1855 przestał być członkiem gminy wyznaniowej, ale nie wiemy, czy gmina w jakiś sposób zareagowała na tę konwersję. Gustaw, aż do przejścia na katolicyzm w r. 1885, był z gminą związany co najwyżej nominalnie, ale nawet już po konwersji gmina krakowska powierzała mu dostawy koszernej mąki. Prasa wspominała o niechęci podgórskich ortodoksów/chasydów do Gustawa ${ }^{175}$, więc gmina podgórska prawdopodobnie kupowała macówkę w innych młynach.

W Krakowie i Podgórzu nie zapomniano wprawdzie o żydowskim pochodzeniu Baruchów/Włodzimirskich, ale od samego początku istnienia ich przedsiębiorstwa - ze względu na lokalizację i fakt, że dawały zatrudnienie miejscowej ludności oraz korzystały z rodzimych produktów - były traktowane

171 W obronie krajowej dachówki, „Przemysł ceramiczny”, 1, 1.12.1910, s. 3; Przemysł dachówkarski, „Przemysłowiec” 23, 5.03.1904, s. 11; W obroni krajowego przemysłu dachówek, „Przemysłowiec” 10, 3.12.1904, s. 13.

172 Ogłoszenie braci Wohlfeld, „Czas” 75, 31.03.1896, s. 5. Nie potrafię odpowiedzieć na pytanie, czy do upadku przedsiębiorstwa baruchowskiego przyczyniło się założenie w Podgórzu szkoły ceglarskiej, patrz Dział ekonomiczny, „Czas” 234, 13.10.1899, s. 3.

173 Z Podgórza, GN 59, 28.02.1909, s. 3.

174 Kronika, NR 278, 30.11.1911, s. 2.

175 Z kraju, GN 141, 23.06.1898, s. 1-2. 
jako „nasze-krajowe”. Podjęcie działalności przemysłowej rozumiano w tym kontekście jako czyn patriotyczny. Opozycja nasze-obce była podkreślana przez tak wielu sprawozdawców prasowych, że musiała odgrywać dużą rolę w dyskursie publicznym. W tym wypadku i w tym okresie wyznanie przedsiębiorców odgrywało raczej niewielką rolę. Mimo upadku przedsiębiorstwa i krytyki sposobu traktowania wieloletnich pracowników nie znalazłam ani jednego komentarza wskazującego na wcześniejszą konfesjonalno-etniczną przynależność podgórsko-łagiewnickich kapitalistów.

Na marginesie trzeba jeszcze zaznaczyć, że kontakty biznesowe przedsiębiorców, np. adresy fabryk, z których sprowadzano maszyny i sprzęt, pozwalają naszkicować drogi modernizacji przedsiębiorstw galicyjskich prowadzące ze Śląska, Węgier i Dolnej Austrii. Częścią składową transferu technologicznego był napływ sił fachowych. Paradoksalnie - to dzięki wysiłkowi nietutejszych "zagraniczne" technologie ulegały "galicyzacji” i stawały się swojskie/krajowe.

\section{Bibliografia}

\section{Prasa}

„Czas” (1850-1900).

„Nowa Reforma” (1882-1914).

„Głos Narodu” (1883-1914).

„Naprzód” (1892-1914).

„Sprawiedliwość Die Gerechtigkeit” (1893-1903):

„Przemysłowiec” (1903-1911).

„Podgórzanin” (1900).

„Gazeta Młynarska” (1886-1889).

„Przemysł ceramiczny” (1901-1903).

\section{Opracowania}

Buchen T., 2010, Herkules im antisemitischen Augiasstall: Joseph Samuel Bloch und Galizien in der Reaktion auf Antisemitismus in der Habsbugermonarchie, [w:] Einspruch und Abwehr. Die Reaktion des europäischen Judentums auf die Entstehung des Antisemitismus (18791914), Hrsg. Ulrich Wyrwa, Frankfurt/M., s. 205-208.

Demel J., 1967, Życie gospodarcze i społeczne ziemi krakowskiej (1848-1867), Kraków.

Demel J., 1958, Stosunki gospodarcze i społeczne Krakowa w latach 1853-1866, Wrocław.

Feldstein H., 1917, Vermögens- und Zahlungsbilanz Galiziens, Leipzig-Wien.

Follprecht K., Krakowskie winiety papierów firmowych (w druku).

Follprecht K., Baruchowie, [w:] Encyklopedia Krakowa (w druku).

Frühwirth H., 2000, Die Doppelstadt Krems-Stein - ihre Geschichte von 1848-2000, Melk.

Girtler K., 1971, Opowiadania. T. 2: Pamiętniki z lat 1832-1857, Kraków.

Grodziska K., 2003, Zaduszne ścieżki. Przewodnik o cmentarzu Rakowickim, Kraków. 
Kargol T., 2003, Izba Przemysłowo-Handlowa w Krakowie w latach 1850-1939: dzieje - ludzie polityka gospodarcza, Kraków.

Katalog krajowej wystawy rolniczej i przemysłowej we Lwowie 1877, 1877, Lwów.

Katalog Powszechnej Wystawy Krajowej we Lwowie roku 1894, 1894, Lwów.

Katalog wystawy rolniczo przemysłowej $w$ Wieliczce w r. 1883, 1883, Kraków.

Katalog wystawy przemystu budowlanego we Lwowie 1892, 1892, Lwów.

Kostuch B., 2011, Krakowskie fabryki kafli w drugiej połowie XIX i na początku XX wieku, „Krzysztofory” 29, s. 229-240.

Lipp A., 1870, Verkehrs- und Handels-Verhältnisse Galiziens, Prag.

Lipszyc M.A., 1901, Wirtschaftliche Studien über Galizien unter besonderer Rücksichtnahme auf die gewerbliche Arbeiterfrage, Zürich.

Nowolecki A., 1878, Wykaz ulic, placów, kościołów i domów miasta Krakowa i Podgórza, Kraków.

Partridge A., 2017a, Libanowie, Fränklowie, Kadenowie, Zuliani, Godziccy: krakowskie rodziny działające w branży budowlanej na przełomie XIX i XX wieku, „Rocznik Krakowski”, 83, s. 187-207.

Partridge A., 2017b, Potęga ornamentu. Europejska ceramika artystyczna $w$ budownictwie $z$ lat 1840-1939 i jej przykłady w obiektach architektury Krakowa, Kraków.

Pawlewski B., Przemysł fabryczny Galicyi, [w:] Powszechna Wystawa Krajowa we Lwowie wr. 1894, 1896, Kraków.

Rutkowski T., 1886, Przemysł młynarski w Galicyi. Historia i statystyka, [w:] Roczniki statystyki przemystu i handlu krajowego, 1: Młynarstwo, Lwów.

\section{Aneks 1: Sprawozdanie z wystawy VII, NR 258, 11.11. 1887, s. 2.}

„Najstarsza może cegielnia p. Maurycego Barucha w Łagiewnikach.- [!] bo założona jeszcze w r. 1854 - przedstawiła wyroby z gliny w licznych okazach, które powszechnie znane są w kraju jako doskonałe. -[!] Firma ta ma tak ustaloną najlepszą reputacyę, że zbytecznem byłoby tutaj zapuszczać się w szczegóły i ocenę jej wyrobów powszechnie znanych. Cegielnia p. Barucha wystawiła przed pawilonem maszyn gospodarczo-rolniczych w zgrabnem ugrupowaniu okazy cegły zwyczajnej ręcznej, maszynowej, ręcznie podwójnie prasowanej i ogniotrwałej, cegły posadzkowe, gzymsowe i wyroby terra-kottowe[!]. Zauważyliśmy zarazem okazy cegieł kolorowanych, których szkliwa dosyć czysto i cało wypadły. Zasługą tej fabryki byłoby wydoskonalenie i staranie się o rozmaitość ubarwienia cegieł, które dzisiaj coraz więcej znajdują użycie do ozdabiania budynków niewyprawionych, osobliwie we Francyi, a u nas potrzeba było takie cegły kolorowane sprowadzać z zagranicy. Dalej wystawiono okazy dachówki płaskiej, tak zwanej karpiówki i tak zwanych gąsiorów o kilku barwach. Krycie dachów zwykłą dachówką było dawniej zwyczajem - jak świadczy jeszcze dzisiaj kilka budynków starych w Krakowie, czerwieniących się ceglanymi dachami. -[!] Później pokrycie to wyparła blacha i łupek które zyskały obywatelstwo przez kilka zalet, t.j. lekkość pokrycia i szybkość pokrywania, chociaż mają one z drugiej strony wiele także wad. Gdyby pokrycie dachów dachówką nie wymagało bardzo silnych i wysokich dachów, a zarazem 
grubszych murów, to przy naszych stosunkach atmosferycznych byłoby to jedyny zadawalniający [!] materiał do pokrywania budynków, zadawalniający nas nie tylko pod względem konstrukcyjnym, ale też estetycznym. -[!] Mamy przekonanie, że temu celowi odpowie dachówka tak zwana „Falzziegel” już dawno rozpowszechniona we Francyi. Okazy tego rodzaju dachówek przedstawiała cegielnia p. M. Barucha, a fabrykacyi [!] tej można rokować pomyślną przyszłość, jeżeli wyrób odpowie wymaganiom lekkości, szczelności i trwałości [...] W dziale wystawy pieców kaflowych zaledwie kilku przemysłowców wystawiło swoje wyroby, a bardzo wielu nie wzięło udziału w wystawie. Ruchliwa i przedsiębiorcza firma p. Maurycego Barucha nadesłała liczne okazy pieców, począwszy od poważnego skromnego pieca z kafli śnieżnej białości, a skończywszy na bogatych, ozdobnych i barwnych piecach z kominkami. -[!] Mając kafle ładne i starannie zrobione, to jeszcze nie wszystko - co potrzeba - ażeby piec był ładny i dobry. W tym względzie z okazów na wystawie w ogóle sądzić nie można, gdyż piece zestawiono na sucho z kafli. Aby piec był dobry i ładny, to zależy głownie od wprawy i zręczności robotnika ustawiającego piec. Że fabryka pieców p. M. Barucha potrafiła wyrobić sobie zręcznych i wprawnych stawiaczy to znaną i wiadomą powszechnie jest rzeczą nawet poza granicami kraju. Oprócz powyżej wymienionego pieca z białych kafli znajdowały się na wystawie 2 piece wraz $\mathrm{z}$ kominkami. Jeden $\mathrm{z}$ nich gustowny pod względem formy i ładnego rysunku, czarny, z górną nasadą z kafli białych - co nie możemy uważać za szczęśliwe zestawienie. Oglądaliśmy także elegancką kuchnię kaflową z wszelkimi urządzeniami i wygodami w celach sztuki kucharskiej, która zachwycała gospodynie - niestety wiele $\mathrm{z}$ nich po przeczytaniu ceny odchodziło z ostudzonem pragnieniem".

Aneks 2: Kronika, (zas" 144, 26.06.1895, s. 2.

„Poświęcenie sztandaru. W kościele parafialnym w Podgórzu odbyło się wczoraj o godzinie 10 rano poświęcenie sztandaru, należącego do zastępu robotników kaflarskich w fabrykach p. Karola Włodzimierskiego. Sztandar ozdobiony jest z jednej strony figurą Matko Boskiej, z drugiej figurą św. Floryana. Po nabożeństwie odprawionem przez X. Wędzichę pani Cecylia Włodzimirska, żona właściciela fabryki, ofiarowała odpowiedni dla sztandaru medalion, zaś pani Weiglowa szarfy z napisem: „Szczęść Boże”. Przy poświęceniu sztandaru jako rodzice chrześni [!] wystąpili oprócz pp. Karolów Włodzimirskich, zaproszenie obywatele, oraz ich żony z Krakowa i Podgórza, wreszcie dopełniono ceremonii wbicia gwoździ do sztandaru. W uroczystości brali udział, oprócz rodziny gospodarza, JE fmp. Bar. Waldstätten ${ }^{176}$, w zastępstwie komendanta korpusu JE fmp. Bar Albori ${ }^{177}$, XX kan. Sherscheń i Drohojowski, prof. Dr. Zoll, prezes Baranowski, p. nadinspektor Szuszkiewicz, prof. Dr Jordan, p. dyrektor Franciszek Ślęk, posłowie Asnyk, Weigel, p. Karol Zaremba,

\footnotetext{
${ }^{176}$ Georg Freiherr von Waldstätten (1837-1918), oficer i tajny radca, dowódca artylerii.

177 Eugen Freiherr von Albori (1838-1915) oficer armii austr.-węg., pod koniec kariery $\mathrm{w}$ randze generała infanterii.
} 
Wacław Adamski i naczelnik straży pożarnej p. Eminowicz. Następnie odbyło się przyjęcie wszystkich gości powyższych, tudzież grona robotników w pięknie przybranej sali młyna parowego. - Właściciel fabryki pan Karol Włodzimirski w przedmowie swojej podniósł znaczenie społeczne uroczystości, podziękował rodzicom chrzestnym oraz uczestnikom, wznosząc na ich cześć toast w ręce pani Weiglowej, jako pierwszej matki chrzestnej, i w ręce, JE fmp. Bar Waldstätten. JE fmp. Waldstätten podziękował serdecznie za daną sposobność zobaczenia tak pocieszających harmonijnych stosunków, panujących między właścicielem a robotnikami i wzniósł zdrowie szefa tych zakładów, p. Karola Włodzimirskiego. Po dalszych toastach składała życzenia swoje deputacya [!] robotników, dziękując za opiekę i pomoc". 